\title{
WestVirginiaUniversity
}

THE RESEARCH REPOSITORY @ WVU

Graduate Theses, Dissertations, and Problem Reports

2012

\section{Manufacture and Properties of Thermoplastic Starch Biocomposites}

Charlie A. Collins II

West Virginia University

Follow this and additional works at: https://researchrepository.wvu.edu/etd

\section{Recommended Citation}

Collins, Charlie A. II, "Manufacture and Properties of Thermoplastic Starch Biocomposites" (2012).

Graduate Theses, Dissertations, and Problem Reports. 3603.

https://researchrepository.wvu.edu/etd/3603

This Dissertation is protected by copyright and/or related rights. It has been brought to you by the The Research Repository @ WVU with permission from the rights-holder(s). You are free to use this Dissertation in any way that is permitted by the copyright and related rights legislation that applies to your use. For other uses you must obtain permission from the rights-holder(s) directly, unless additional rights are indicated by a Creative Commons license in the record and/ or on the work itself. This Dissertation has been accepted for inclusion in WVU Graduate Theses, Dissertations, and Problem Reports collection by an authorized administrator of The Research Repository @ WVU.

For more information, please contact researchrepository@mail.wvu.edu. 
Manufacture and Properties of Thermoplastic Starch Biocomposites

\title{
Charlie A. Collins II
}

Dissertation submitted to the Davis College of Agriculture, Forestry and Consumer Sciences at West Virginia University in partial fulfillment of the requirements

for the degree of

Doctor of Philosophy

in

Forest Resources Science

Ben Dawson-Andoh, Ph.D., Chair

Eugene Felton, Ph.D.

Laurent Matuana, Ph.D.

John Renton, Ph.D.

Ben Spong, Ph.D.

Department of Wood Science and Technology

\author{
West Virginia University \\ Morgantown, West Virginia \\ 2012
}

Keywords:

Starch, Biocomposites, Lignin, Processability, Biodegradation, Properties 


\section{ABSTRACT \\ Manufacture and Properties of Thermoplastic Starch Biocomposites}

\section{Charlie A. Collins II}

Bio-composites have attracted considerable attention from the industry as potential substitutes for petroleum-derived composites. Starch is a potential candidate because it is biodegradable and is readily available sustainable polymer from agriculture resources. However, it is not easy to process like petroleum-derived polymers because of the lack of defined melting point and is sensitive to high humidity with poor mechanical properties. This study evaluated the processability of starch, lignin and pulp fibers using a Brabender ${ }^{\circledR}$ Torque Rheometer. Type of starch exerted great influence on processability. Gelation characteristics of the four composite mixtures correlated with starch type. Amylose containing composite mixtures (\#1 and \#2) was associated with higher gelation characteristics. The lowest gelation torques and energies were exhibited by composites \#3 and \#4 (amylopectin starch). This can be attributed to the crystallinity melting temperature of the two starch composites. Amylopectin is the more crystalline structure of the two starches, so therefore would have the greater influence on such things as hardness, modulus, tensile and even stiffness, respectfully. Higher mechanical properties were associated with starch bio-composites containing amylopectin. Composites \#1 and \#4 exhibited the highest water absorption and Composites \#2 and \#3 exhibited the lowest water absorption; the type of lignin used as filler made a greater contribution of the hydrophobicity of the starch composites. Moisture content of all starch composites was similar between all starch-lignin composites (16\% - 17\%). Fourier Transform Infrared spectra analysis of composites showed the absence of any discernible chemical bonds. Bio-composites containing amylopectin exhibited the highest glass transition. Thermal degradation patterns for all starch composites were different. Mass loss below $100^{\circ} \mathrm{C}$ was associated with loss of water. Loss of glycerol commenced around $200^{\circ} \mathrm{C}$ and its thermal degradation was completed around $300^{\circ} \mathrm{C}$. Thermal degradation of pulp fiber occurred in two stages: $230^{\circ} \mathrm{C}$ and $230-390^{\circ} \mathrm{C}$ where the largest mass loss occurred. Scanning electron microscope showed that pulp fibers were not well dispersed and aligned within the composites. Biodegradation of the samples were examined from a 6-hr period to a 48-hr period. Biodegradation of the four composite mixtures correlated with starch type. Amylose containing composite mixtures (\#1 and \#2) was associated with similar digestion rates; Composite \#1 biodegrades at $12.13 \% / \mathrm{hr}$. and Composite \#2 biodegrades at $12.95 \% / \mathrm{hr}$. The best digestion rate was exhibited by amylopectin containing mixture Composite \#3 biodegrades at $14.00 \% / \mathrm{hr}$. and Composite \#4 biodegrades at $7.26 \% / \mathrm{hr}$., making it the composite that takes the longest to biodegrade. Therefore, meaning that the interaction between the composites fillers has an effect on the digestion rates of the starch-lignin composites. 


\section{DEDICATION}

To Mr. and Mrs. Charlie Collins, my parents, for all their love, sacrifice, encouragement, support and faith

To Charlie James Collins, my son, for helping me understand what it means to be a father

To family, friends and the haters, without your constant inclusion in my life, this would have never been possible

$\&$

To all who have contributed to the successes I have made in my educational and social achievements starting from my elementary education to this award of Doctoral degree 


\section{ACKNOWLEDGEMENTS}

I know that I could not have done this without my Lord and Savior, Jesus Christ!

I would also like to acknowledge the entire member of my doctoral dissertation defense committee for their time, discussions and comments during the course of this research work and writing the dissertation.

I am eternity grateful to Dee Curtis, Mr. and Mrs. Rivers, Dr. Matuana \& his facilities at Michigan State University, all the good people in Agriculture Science, Engineering, Physics and Chemistry who assisted me with this research and data interpretation. Also, I would like to thank my numerous colleagues and research members for their assistance during the course of my research at West Virginia University.

Finally, I would like to thank my family, friends, Dr. Dawson-Andoh, Jennifer McIntosh, the Forestry Department at West Virginia University, the Biology Department at West Virginia University and all of the great people that I have met while completing my studies at West Virginia University. I definitely could not have done this without you all!! 


\section{TABLE OF CONTENTS}

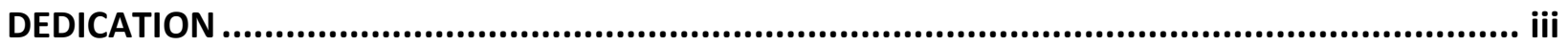

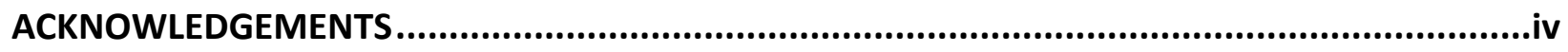

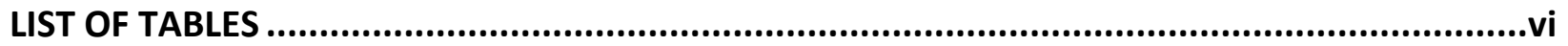

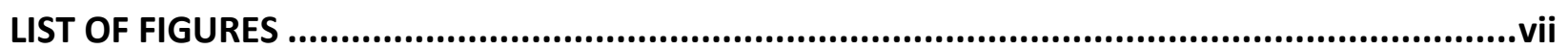

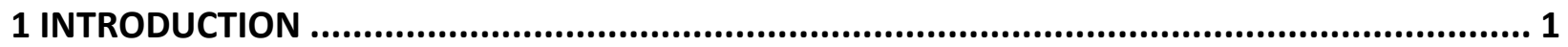

2 OBJECTIVES AND DISSERTATION STRUCTURE............................................................. 3

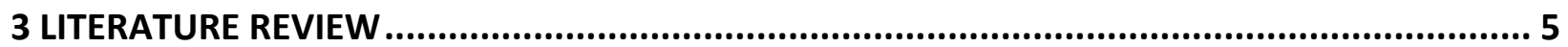

4 PROCESSING CHARACTERISTICS OF STARCH-LIGNIN BIOCOMPOSITES REINFORCED WITH

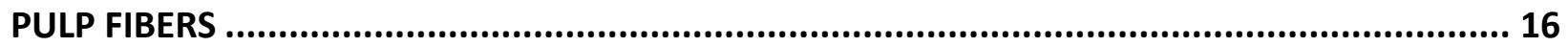

5 MECHANICAL AND CHEMICAL PROPERTIES OF STARCH BIO-COMPOSITES REINFORCED

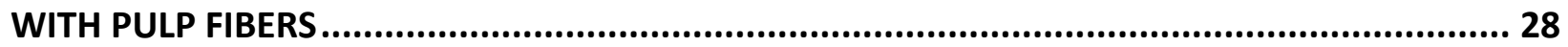

6 BIODEGRADATION OF STARCH-LIGNIN BIOCOMPOSITES REINFORCED WITH PULP FIBERS 49

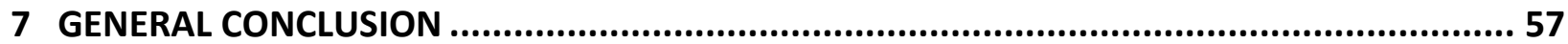

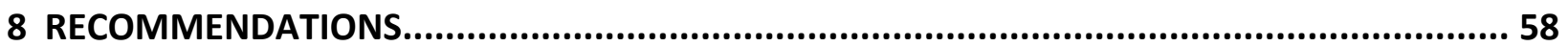




\section{LIST OF TABLES}

Table 1. Gelation-Melt Properties of Composite Mixtures ...................................................... 23

Table 2. Composition of Composites Mixtures ..................................................................... 24

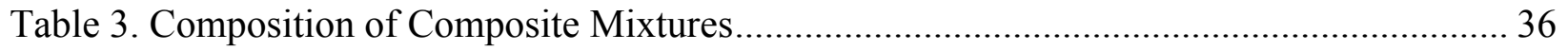

Table 4. Mechanical Properties of Composites - Tensile ....................................................... 37

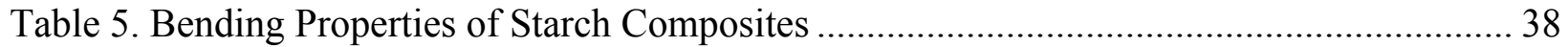

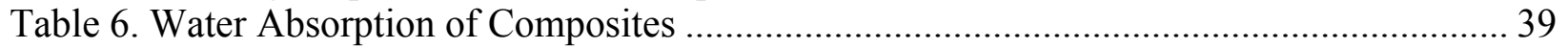

Table 7. Differential Scanning Calorimetry of Composites ................................................ 41

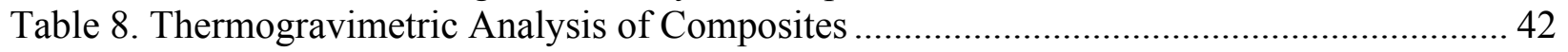

Table 9. Biodegradability of Starch-Lignin Biocomposites ................................................... 54 


\section{LIST OF FIGURES}

Figure 1. Concept of "Sustainable” Bio-Based Product ......................................................... 5

Figure 2. Molecular Structure of Starch ............................................................................ 8

Figure 3. Chemical Structure of Glycerol Molecule........................................................... 8

Figure 4. Three Primary Molecular Structure of Lignin.................................................... 10

Figure 5. Molecular Schematic Structure of Lignin .............................................................. 10

Figure 6. Gelation-Melt Curves of Composite Mixtures ........................................................ 22

Figure 7. Fourier Transform Infrared Spectra of Starch Composites .................................... 40

Figure 8. 300x Top View of Composite \#1 ...................................................................... 43

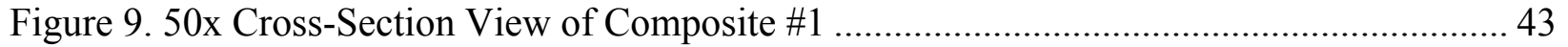

Figure 10. 5000x Top View of Composite \#2 ...................................................................... 44

Figure 11. 50x Cross-Section View of Composite \#2 ........................................................ 44

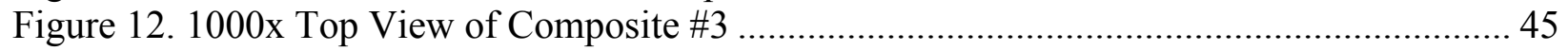

Figure 13. 50x Cross-Section View of Composite ................................................................ 45

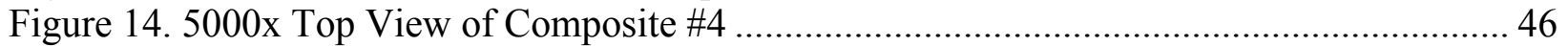

Figure 15. 50x Cross-Section View of Composite \#4 ...................................................... 46 


\section{INTRODUCTION}

Bio-composites are emerging as important alternatives to petroleum-based composites. Potentially, they form the basis of sustainable, eco-efficient products that can substitute petroleum-based composites. These petroleum-based composites exert negative impact on the environment. They continue to be present in the environment even at the end of their service life because they are not biodegradable. Bio-composites include composites manufactured from renewable agricultural and forestry-feed stocks such as wood, wood wastes/residues, grasses, agriculture crops and by-products. Bio-composites manufactured from renewable agricultural and forestry-feed stocks are biodegradable and therefore more eco-friendly for the environment.

Starch, an agriculture polymer (agro-polymer) is a versatile bio-polymer with pronounced potential for use in non-food industries. However, unlike petroleum-derived polymers such as polyethylene and polypropylene, it cannot be processed in its native state. One way starch can be

processed as a polymer is by its conversion to a thermoplastic form. Starch can be made a thermoplastic in the presence of specific amounts of plasticizers (water and/or poly-alcohols) under specific conditions. Starch consists of two types of polymers: Amylose and Amylopectin. Amylose is a sparsely branched carbohydrate mainly based on $\alpha$ - $(1,4)$ bond with a molecular weight of $10^{5}-10^{6}$. Amylose is soluble in water and forms a helical structure. Starch granules exhibit hydrophilic properties and strong inter-molecular association via hydrogen bonding formed by the hydroxyl groups on the granule surface (Lu et al 2009, Ramesh et al 1999 and Wallace et al 1981).

Amylopectin is a component of starch that has a high molecular weight and branched structure and does not gel in aqueous solutions. Each Amylopectin molecule may contain $100,000-200,000$ glucose units, and each branch is about 20 or 30 glucose units in length, so that these molecules are bushy and nearly spherical in shape. Amylopectin is one fraction of starch (typically $80-90 \%$ ), the other fraction being amylose (10-20\%). The plasticizer to be used in this study, glycerol, $\mathrm{C}_{3} \mathrm{H}_{8} \mathrm{O}_{3}$, is a trihydroxy sugar alcohol that is colorless, odorless and sweet-tasting liquid.

The major drawbacks of starch-based bio-composites are sensitivity to humidity, moisture, poor physical and mechanical properties. These drawbacks can be eased by two methods: chemical modification of starch and physical modification of the bio-composites 
through the inclusion polymers as fillers. The latter can be petroleum or agriculture/forestrybased. Two major forestry-based polymers, cellulose/hemicellulose (recycled pulp fibers) and lignin were used in this study. Lignin, a waste product of chemical pulping, is hydrophobic and can therefore improve the sensitivity of starch-based bio-composites to humidity and moisture. However, the hydrophobicity of lignin reduces its compatibility with starch reducing its adhesion and potentially its mechanical properties. Pulp fibers, which consist of cellulose and some hemicellulose, are hydrophilic and therefore more compatible with starch. Potentially, the use of lignin and pulp fibers as fillers in plasticized starch-based bio-composites and can contribute significantly to the mechanical properties of the bio-composites.

\section{References}

1. Lu, D., Xiao, C., Xu, S. Starch-based completely biodegradable polymer materials. eXPRESS Polymer Letters. 2009, Vol. 3, No. 6, 366-375.

2. Ramesh, M., Mitchell, J. and Harding, S. Amylose content of rice starch. Starch. 1999, 51, 311-313.

3. Wallace, R., King, J. and Sanders, G. Biology - The Science of life. California: Goodyear Publishing Company edition 1981. 


\section{OBJECTIVES AND DISSERTATION STRUCTURE}

\subsection{Objective of Study}

The overall objective of this study is to process and investigate the physical, mechanical, chemical and biodegradability of starch-lignin biocomposites reinforced with pulp fibers. Specific objectives are:

1. To study the effect of type of starch and agro-polymers on their processability by plasticization of starch and formation of melts with fillers,

2. To study the effect of type of starch and agro-polymers fillers on the mechanical properties on plasticized-starch bio-composites,

3. To study the effect of type of starch and agro-polymers fillers on the physical and chemical properties of the plasticized-starch bio-composite,

4. To study the effect of the type of starch and agro-polymers fillers on the biodegradability of the plasticized bio-composites. 


\subsection{STRUCTURE OF DISSERTATION}

This dissertation consists of three unpublished articles and three opening chapters and two chapters on overall Conclusion and Recommendations:

I. Chapter 1. Introduction

II. Chapters 2. Objectives

III. Chapter 3. Literature Review

IV. Chapter 4. Processing Characteristics of Starch-Lignin Composites

V. Chapter 5. Study of the Mechanical and Chemical Properties of StarchLignin Biocomposites Reinforced with Pulp Fibers

VI. Chapter 6. Biodegradation of Starch-Lignin Biocomposites Reinforced with Pulp Fibers

VII. Chapter 7. Overall Conclusion

VIII. Chapter 8. Recommendations 


\section{LITERATURE REVIEW}

\subsection{Bio-Based Composites}

Green materials are the wave of the future. There is immense opportunity to develop new biocomposites, but the real challenge is to design sustainable bio-composites. Development of biocomposites is driven by new environmental regulations and societal concern about the negative impact of current fossil-derived composites. The incorporation of agriculture-derived polymers (agro-polymers) in composite materials can reduce further dependency on petroleum reserves (Mohanty et al 2002).

Bio-composites can supplement and eventually replace fossil-based composites in many applications, offering new agricultural, environmental, manufacturing and consumer benefits. Because bio-composites are derived from renewable resources, materials costs can be markedly reduced with their large-scale usage. Their unique balance of properties would open up new market development opportunities in the 21st century (Mohanty et al 2002). A bio-based composite derived from renewable resources having recycling capability and triggered biodegradability (i.e., stable in their intended lifetime but would biodegrade after disposal in composting conditions) with commercial visibility and environmental acceptability is defined as a "sustainable" bio-based product (Figure 1, Mohanty et al 2002).

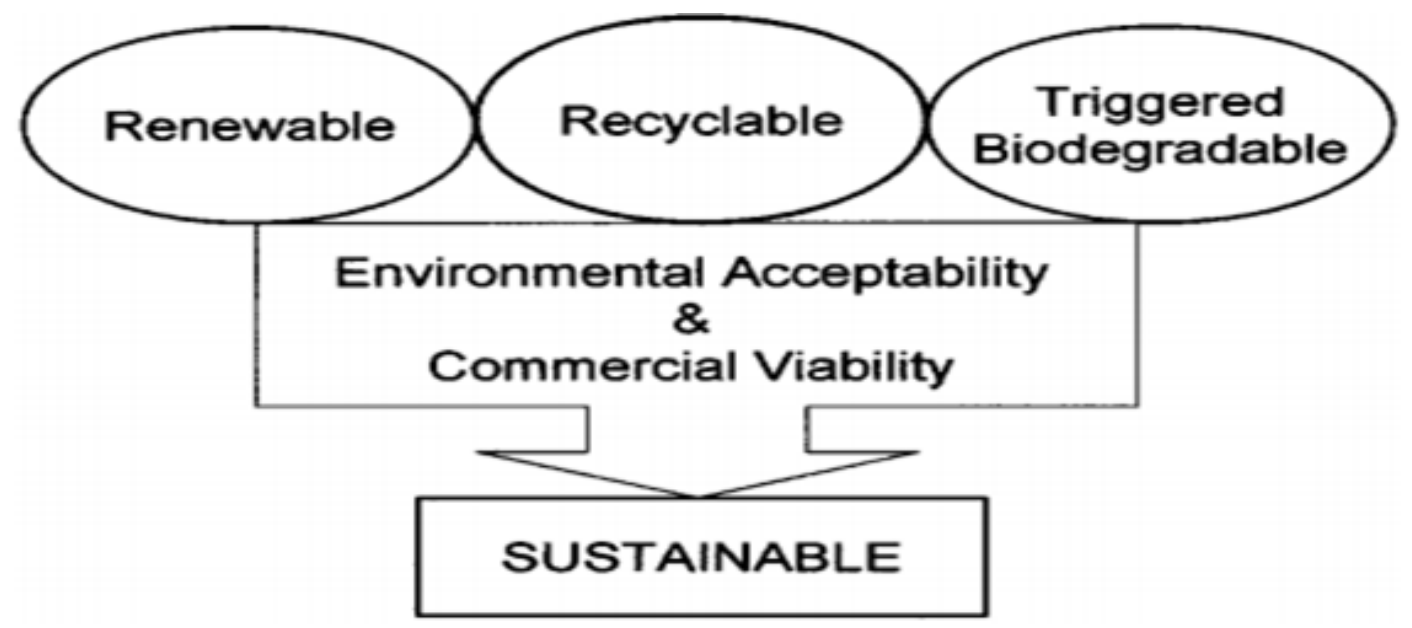

Figure 1. Concept of "Sustainable" Bio-Based Product 
The potential advantages of bio-composites are their biodegradability via microbial action in compost piles or at sea rather than accumulating in landfills and waterways. In addition to these environmental advantages, agro-polymers such as starch are attractive to the emerging biocomposite interest because of low-cost and availability. Moreover, the use of starch in the manufacture of bio-composites will reduce dependence on synthetic polymers made from imported oil and offers socio-economic benefits because it generates rural jobs and a non-food agricultural-based economy (Dufresne et al 2000).

\subsection{Potential of Bio-Based Products}

It is now widely accepted that fossil-based polymers that remain in the environment at the end of the service life but are used for short-term applications such as packaging, agriculture, catering and hygiene are not sustainable. Increasing concerns exist about the preservation of ecological systems and the increase in polymer waste streams. Specifically, most of today's synthetic polymers are produced from petrochemical resources in which most are not biodegradable. These long-life polymers are a significant source of environmental pollution, damaging wildlife when they are 'accidentally' dispersed. The use of agro-polymers can preserve petroleum resources by replacing the polymers based on petroleum resources for some applications; this is in agreement with the concept of sustainability. In fact, agro-polymers can be used to overcome the limitations and the increasing prices of petroleum-based resources and can contribute to a significant reduction of carbon dioxide $\left(\mathrm{CO}_{2}\right)$ emissions in the future (Averous et al 2009).

Agro-polymers are mainly extracted from plants; are compostable and renewable and hydrophilic. These polymers can be used processed directly or chemically modified and used as fillers or plasticized and used as a matrix in the manufacture of a bio-composite. Specifically, there are different types of agro-polymers, such as polysaccharides, proteins (e.g., gluten or zein) and lignin. The most abundant are the polysaccharides with different products and structures, such as cellulose, chitin and starch (Averous et al 2009).

The classification of biodegradable polymers is split into four families. The first family is agropolymers (e.g., polysaccharides) obtained from biomass by fractionation. The second and third families are polyesters, obtained, respectively by fermentation from biomass or from genetically modified plants and by synthesis from monomers obtained from biomass. The fourth family, 
which is of fossil origin, is polyesters that are totally synthesized by the petrochemical process (Averous et al 2004).

\subsection{Starch}

The use of starch for the manufacture of paper and papyrus appears to have been known to the Egyptians, and traces of a starch adhesive have been found on documents dating about $3500 \mathrm{BC}$ (Radley et al 1943). Early specimens of paper clearly indicate of having been sized and weighed with a crude starch. In $170 \mathrm{BC}$, the Romans used a process that separated starch from grain. Three hundred years after that, Celsus, a Greek physician, described starch as a wholesome dietary product. It was also used to produce an "artificial honey" which when combined with saliva, was applied to wounds (Radley et al 1943).

Starch is a complex carbohydrate that is found in the seeds of cereal plants. It is manufactured during photosynthesis and serves as energy storage for plants. Once the starch has been separated and dried, it becomes a soft powder that remains stable indefinitely if kept dry. Even though wheat flour and other starchy vegetables materials have been used to stiffen fabrics for years, it was not until around the 1840's when Brown \& Polson, among others, began manufacturing starch on a commercial basis (Radley et al 1943).

Starch is a polysaccharide consisting of D-glucopyranose units joined by $\alpha-1,4$ linkages and is hydrophilic. Starch consists of two different macromolecules, amylose and amylopectin (Averous et al 2009). Amylose is a sparsely branched carbohydrate bond with a molecular weight of $10^{5}-10^{6}$. Amylopectin is a highly multiple-branched polymer and in addition to the $\alpha$ 1,4 linkages, also has $\alpha-1,6$ linkages with a high molecular weight of $10^{7}-10^{9} .^{2}$ The hydroxyl groups at C-2 and C-3 positions on each glucose residue are free; as well as the primary hydroxyl group at C-6 when it is not linked ( $\mathrm{Lu}$ et al 2009 and Tomasik et al 2004). The available hydroxyl groups on the starch chains potentially exhibit reactivity specific for alcohols. In other words, they can be oxidized and reduced; may participate in the formation of hydrogen bonds, ethers and esters (Lu et al 2009 and Tomasik et al 2004).

Amylose and amylopectin occur in starch and range from 10-20\% amylose and 80-90\% amylopectin depending on the source can be found (Lu et al 2009, Ramesh et al 1999 and Wallace et al 1981). Amylose is soluble in water and forms helical structure. Starch occurs naturally as discrete granules since the short branched amylopectin chains are able to form 
helical structures which crystallize (Lu et al 2009, Ramesh et al 1999 and Wallace et al 1981). A starch granule is hydrophilic with strong inter-molecular association via hydrogen bonding formed by the hydroxyl groups on the granule surface (Figure 2, Lu et al 2009).

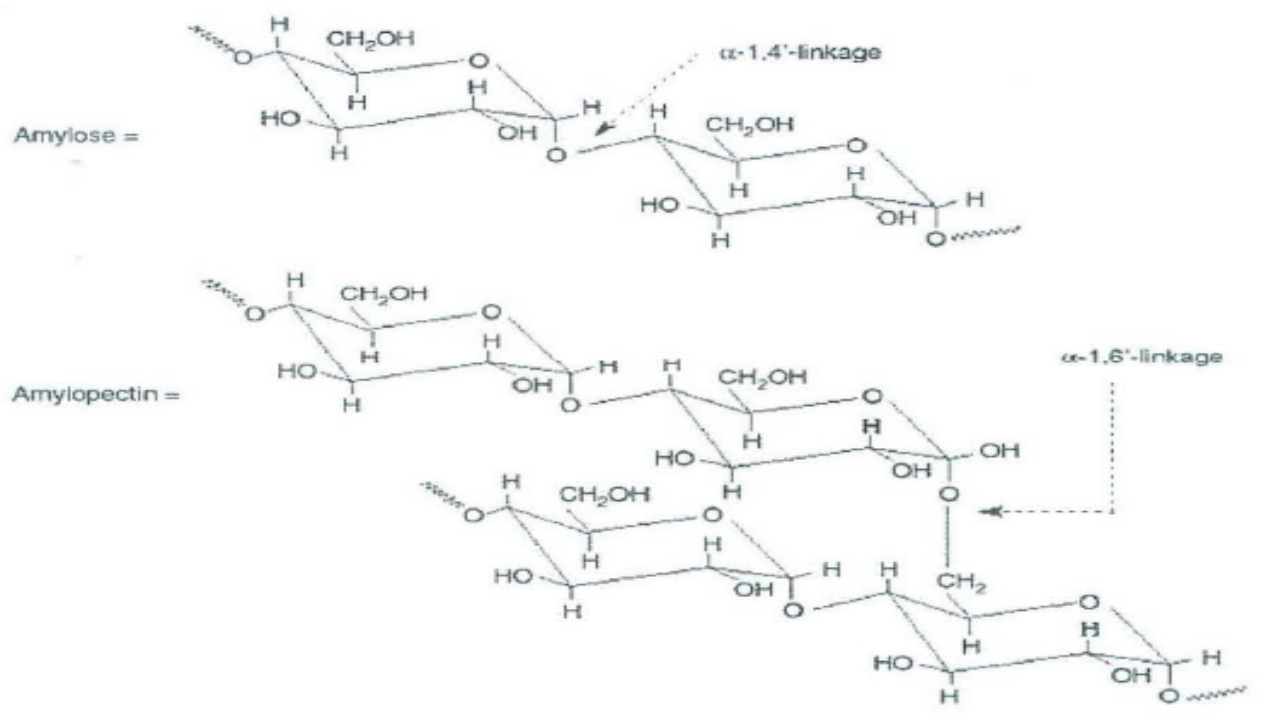

Figure 2. Molecular Structure of Starch

Starch is a low cost material when compared to fossil-based polymers (plastics); additionally it is readily available. Starch is not a true thermoplastic but in the presence of plasticizers at high temperatures $\left(90-180^{\circ} \mathrm{C}\right)$ and under shear, it readily melts and flows, allowing for its use in injection, extrusion or blow molding material, similar to most conventional synthetic thermoplastic polymers (Curvelo et al 2001).

\subsection{Glycerol}

Glycerol is a colorless syrupy liquid miscible in water in all proportions. As stated before, glycerol's conventional formula is $\mathrm{C}_{3} \mathrm{H}_{8} \mathrm{O}_{3}$ (Figure 3 taken from home.roadrunner.com).

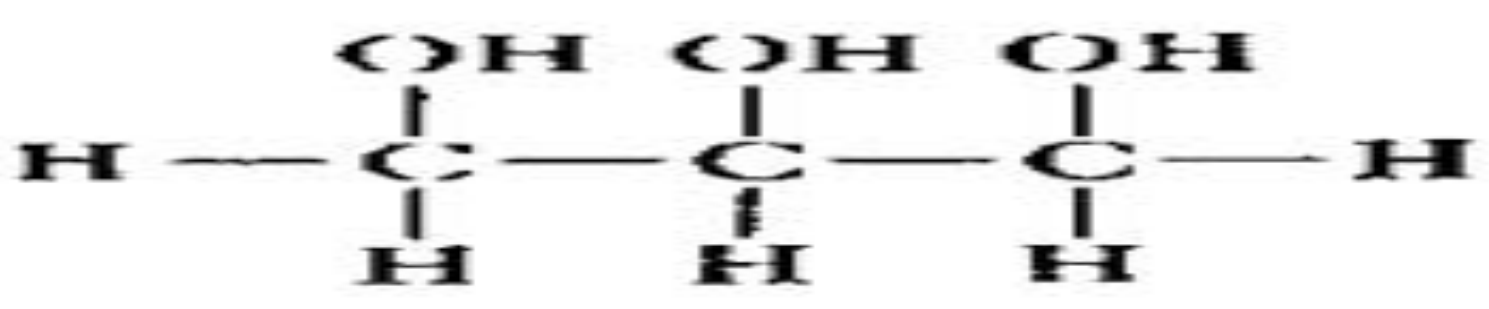

Figure 3. Chemical Structure of Glycerol Molecule 
Recent studies have shown that starch requires the addition of water or complete gelatinization to enable its processability (Averous et al 2009). By decreasing the moisture content (to less than $20 \mathrm{wt} / \mathrm{v} \%$ ), the melting temperature tends to be close to the degradation temperature. For instance, the melting temperature of pure dry starch is $220-240^{\circ} \mathrm{C}$ compared to the temperature of the beginning of starch decomposition, $220^{\circ} \mathrm{C}$ (Averous et al 2009).

Thermoplastic starch or plasticized starch (PLS) has two main disadvantages when compared to most fossil-derived plastics currently in use, i.e. it is mostly water-soluble and has poor mechanical properties (Curvelo et al 2001). To overcome this issue, a non-volatile (at the process temperature) plasticizer, such as glycerol or others polyols (sorbitol, polyethylene glycol), is added to decrease the melting and process temperature (Averous et al 2009). Its water resistance may also be improved by mixing it with certain fossil- or agro-based polymers or by functionalization via crosslinking agents such as calcium $(\mathrm{Ca})$ and zirconium $(\mathrm{Zr})$ salts or adding lignin (Curvelo et al 2001).

\subsection{Lignin}

The word lignin is derived from the Latin word lignum meaning wood and, indeed, lignin form an essential component of the woody stems of arborescent gymnosperms and angiosperms in which their amounts range from 15\% - 36\% wt/v (Sarkanen et al 1971). Lignins are integral part of cell wall constituents in all vascular plants including the herbaceous varieties (Sarkanen et al 1971). They are present in plant stems, foliage and root tissues.

Lignin is an amorphous heterogeneous polymer bio-synthesized via an enzyme-initiated dehydrogenative polymerization of the three primary precursors: 1 . trans-coniferyl, 2 . transsinapyl and 3. trans-p-coumaryl alcohols (Figure 4, Sarkanen et al 1971). Lignins are always associated with hemicelluloses, not only in intimate physical admixture but also anchored to the latter by actual covalent bonds. Secondly, most lignins contain varying amounts of certain aromatic carboxylic acids in ester-like combination. These acids are most probably not generated from the three primary precursors in the dehydrogenative polymerization process (Sarkanen et al 1971). 


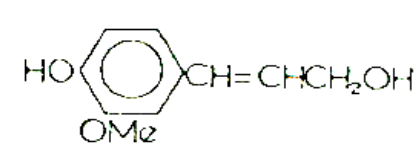

1

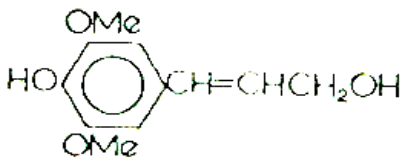

2
$\mathrm{HO}\left\langle\left(\mathrm{CH}=\mathrm{CHKH} \mathrm{CH}_{2}\right.\right.$

3

\section{Figure 4. Three Primary Molecular Structure of Lignin}

The main difficulty in lignin chemistry is that it cannot be isolated in the native state. Although chemical structure of lignin polymer is unknown, most of the functional groups and types of linkages are known (Figure 5, taken from accessscience.com).
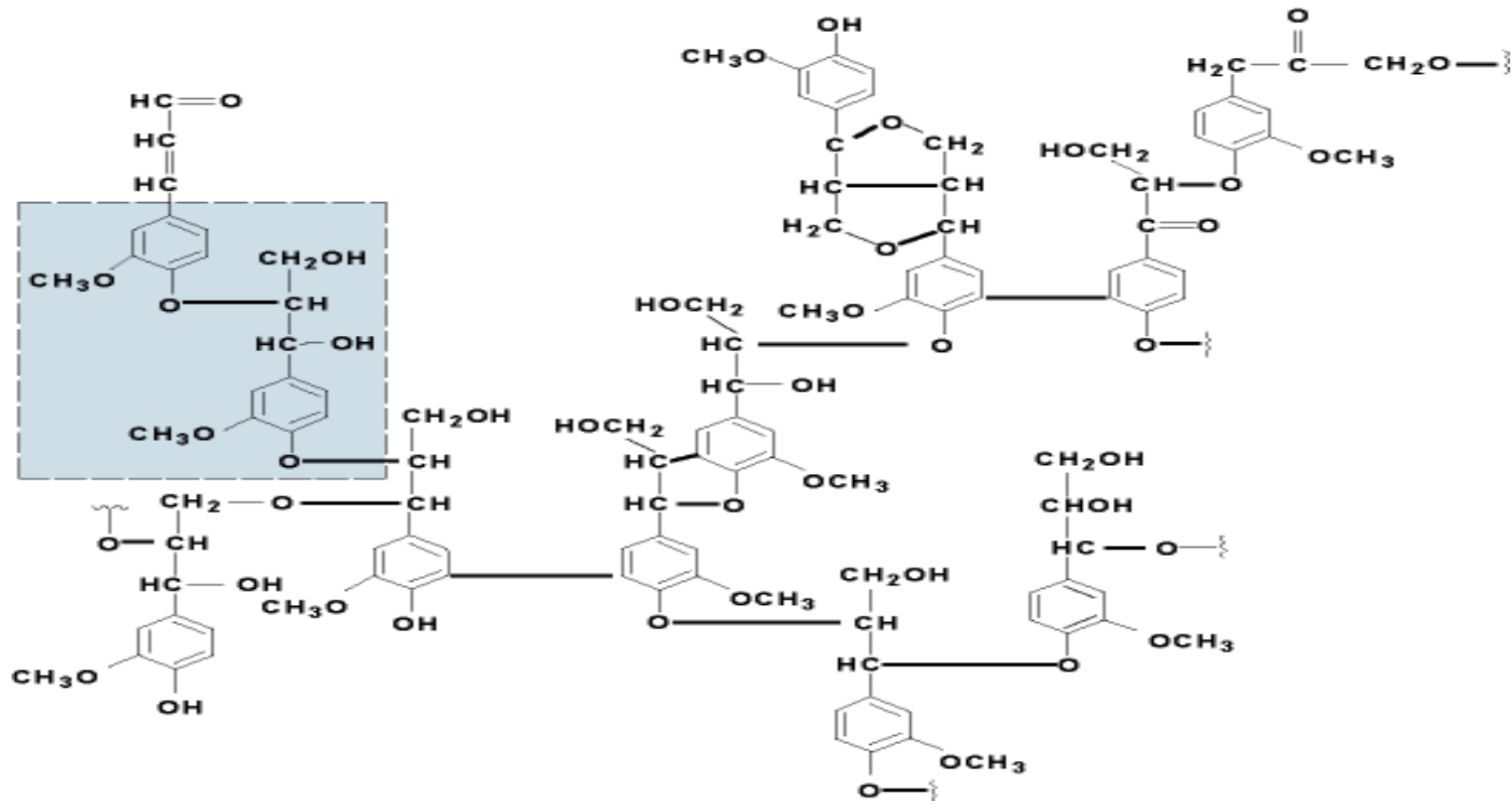

Figure 5. Molecular Schematic Structure of Lignin

Pulping processes produce abundant waste lignin waste product that is primarily burnt to produce heat and recover pulping chemicals in the Kraft Pulping process. They are therefore abundant and cheap. Potential new value-added products of lignin include conversion to carbon fibers or use as reinforcing fillers in bio-composites using matrices such as starch (Spiridon et al 2010 and $\mathrm{Yu}$ et al 2006). Lignin is relatively hydrophobic and poorly soluble in water at acid or neutral $\mathrm{pH}$ unless it contains sodium or ammonium cation as in some Kraft lignin or sulfonic 
acid functional groups as in Sulfite pulps. Lignin biodegrades and is therefore environmentally compatible (Averous et al 2009, Baumberger et al 1998 and Curvelo et al 2001).

Several fossil-based polymers such as polyethylene, propylene have been used as reinforcing fillers in plasticized starch (PLS) bio-composites to improve its mechanical properties. This study seeks to use environmentally compatible agro-polymers as reinforcing fillers in PLS (Averous et al 2009 and Curvelo et al 2001).

\subsection{Cellulose Fibers}

Cellulose is a raw material with a wide variety of uses in the chemical industry for producing man-made textile fibers. Commercial methods of manufacturing man-made cellulosic fibers include viscose, cuprammonium, and several new alternative processes (Kayseri et al 2010).

Cupro, acetate and viscose fibers were developed more than 100 years ago. The use of high tenacity viscose and modal fibers shows that these cellulosic regenerated fibers have not only come a long way but are well-established nowadays. This type of fiber - belonging to the third generation of cellulosic manmade fibers - enables the textile industry to expand its already wide range of applications in function (Kayseri et al 2010).

The use of agro-polymers or fibers to reinforce thermoplastic starch and other biodegradable materials is a new approach (Bledzki et al 1999). Compared to inorganic or petroleum-based fillers, composites that incorporates renewable fibers or polymers are environmentally compatible, low cost, low density, high specific strength and modulus (desirable fiber aspect ratio), high sound attenuation, comparatively easy processability (due to their flexibility and nonabrasive nature, which allow high filling levels, resulting in significant cost savings), and a relatively reactive surface ( $\mathrm{Yu}$ et al 2006).

\subsection{Application of Bio-Based Composite}

Food packaging and edible films are the two major applications of the starch-based biodegradable polymers in the food industry. The requirements for food packaging include reducing food losses, keeping food fresh, enhancing organoleptic characteristics of food such as appearance, odor, and flavor and providing food safety ( $\mathrm{Lu}$ et al 2009). The starch-based 
biodegradable bio-composites represent potential substitutes for current fossil-based food packaging to overcome these disadvantages and keep the advantages of traditional packaging materials (Lu et al 2009).

The industrial development of such starchy materials as food packaging is hindered by their swelling and partial dissolution in moist environments. Chemical modification of starch has proved to be an effective way to reduce its water affinity but to the detriment of cost, potential toxicity and biodegradability. Another approach is to blend starch with hydrophobic compounds (Bledzki et al 2009) with the following benefits (Averous et al 2009):

- Higher mechanical properties. Compared to bio-polyesters-based bio-composites, starch-based bio-composites have superior properties that can be linked to higher interactions between the matrix and filler.

- Higher thermal resistance caused by the transition shift of glass transition (Tg) and an increase in the rubber plateau.

- Reduced water sensitivity due to fiber-matrix interactions owing and to the higher hydrophobic character of the cellulose as result of its high crystallinity.

- Reduced post-processing ageing due to the formation of a 3-D network between the different matrix-filler carbohydrates based on hydrogen bonds.

\subsection{Biodegradation}

Biodegradation is classified into three different types based on the agent that causes it: 1. Direct - which the material uses itself as a source of nutrition; 2. Indirect - when a transformation is caused by microbial agents such as enzymes or acids; and 3. False - deposition without any actual breakdown (Rose 1981). Biodegradation can occur or be slowed down by various biological factors. These factors may be chemicals, such as polymers, or organisms that cause biodegradation such as yeast, fungi or bacteria. To accelerate the process, various bioremediation techniques such as fertilization and seeding are used. Biodegradation also is graded on three different scales: 1 . Inherently Biodegradable $-20 \%-70 \%$ biodegradability of the material within 28 days; 2 . Readily Biodegradable - materials that mineralize rapidly and 
completely; and 3. Nonbiodegradable - insignificant degree of biodegradation by the material (Rose 1981). 


\section{References}

1. Averous, L. Biodegradable Multiphase Systems Based on Plasticized Starch: A Review. Journal of Macromolecular Science. Part C - Polymer Review. 2004, Vol. C44, No. 3, pp. 231-274.

2. Averous, L. and Halley, P. Biocomposites based on plasticized starch. Wiley InterScience. 2009, 3, 329-343.

3. Averous, L. and Boquillon, N. Biocomposites based on plasticized starch: thermal and mechanical behaviors. Carbohydrate Polymers. 2004, 56, 111-122.

4. Baumberger, S., Lapierre, C. and Monties, B. Utilization of Pine Kraft Lignin in Starch Composites: Impact of Structural Heterogeneity. J. Agric. Food Chem. 1998, 46, 2234220.

5. Baumberger, S., Lapierre, C., Monties, B. and Della Valle, G. Use of kraft lignin as filler for starch films. Polymer Degradation and Stability. 1998, 59, 273-277.

6. Bledzki, A.K. and Gassan, J. Composites reinforced with cellulose based fibres. Progame on Polymer Science. 2009, 24, 221-274.

7. Curvelo, A., Carvalho, A. and Agnelli, J. Thermoplastic starch-cellulosic fibers composites: preliminary results. Carbohydrate Polymers. 2001, 45, 183-188.

8. Dufresne A., Dupeyre, D. and Vignon, M. Cellulose microfibrils from potato tuber cells: Processing and characterization of starch-cellulose microfibril composites. $J$ Appl Polym Sci. 2000, 76(14):2080-2092.

9. Kayseri, G. and Bozdogan, F. Performance Properties of Regenerated Cellulose Fibers. Tekstil ve KonFeksiyon. 2010. Vol. 3, 208-212

10. Lu, D., Xiao, C., Xu, S. Starch-based completely biodegradable polymer materials. eXPRESS Polymer Letters. 2009, Vol. 3, No. 6, 366-375.

11. Mohanty, A., Misra, M. and Drzal, L. Sustainable Bio-Composites from Renewable Resources: Opportunities and Challenges in the Green Materials World. Journal of Polymers and the Environment. 2002, Vol. 10, Nos. 1/2, April 2002.

12. Radley, J. Starch And Its Derivatives. London: Chapman \& Hall LTD edition 1943.

13. Ramesh, M., Mitchell, J. and Harding, S. Amylose content of rice starch. Starch. 1999, 51, 311-313. 
14. Rose, A. Economic Microbiology - Volume 6 Microbial Biodeterioration. London: Academic Press edition 1981.

15. Sarkanen, K. and Ludwig, C. Lignins: Occurrence, Formation, Structure, and Reactions. New York: Wiley-Interscience edition 1971.

16. Spiridon, I., Teaca, C., Bodirlau, R. Preparation and characterization of adipic acidmodified starch microparticles/plasticized starch composite films reinforced by lignin. $J$. Material Science. 2011, 46, 3241-3251.

17. Tomasik, P. and Schilling. Chemical Modification of Starch. Advances in Carbohydrate Chemistry and Biochemistry. 2004, Vol. 59, 175-403.

18. Wallace, R., King, J. and Sanders, G. Biology - The Science of life. California: Goodyear Publishing Company edition 1981.

19. Yu, L., Dean, K. and Li, L. Polymer blends and composites from renewable resources. Progress in Polymer Science. 2006, 31, 576-602. 


\title{
4 PROCESSING CHARACTERISTICS OF STARCH-LIGNIN BIOCOMPOSITES REINFORCED WITH PULP FIBERS
}

\author{
C. A. Collins II, L. M. Matuana and B. Dawson-Andoh
}

\begin{abstract}
Starch bio-composites represent potential substitutes for current fossil-based composites. A major drawback of starch composites is its processability because of the lack of defined melting point and its decomposition over a wide temperature change. This study evaluated the processability of starch, lignin and pulp fibers using a Brabender ${ }^{\circledR}$ Torque Rheometer. Type of starch exerted great influence on processability. Gelation-melt characteristics of the four composite mixtures correlated with starch type. Amylose containing composite mixtures (\#1 and \#2) was associated with higher gelation-melt characteristics. The lowest gelation-melt torques and energies were exhibited by composites \#3 and \#4 (Amylopectin starch). This can be attributed to the crystallinity melting temperature of the two starch composites. Amylopectin is the more crystalline structure of the two starches, so therefore would have the greater influence on such things as hardness, modulus, tensile and even stiffness, respectfully.
\end{abstract}

\section{INTRODUCTION}

Starch is a readily available renewable plant derived material. It is a biodegradable polymer with potential as a replacement for petroleum-derived polymers used in the manufacture of composites (Prachyayawarakorn et al. 2010). Starch occurs as an energy storage for plants and is a polymer of $\alpha$-1,4-linked D-Glucose (Gupta et al 2011). It occurs in two forms: amylose and amylopectin. Amylose is a linear anhydrose polymer whilst amylopectin is branched and in addition to the $\alpha-1,4$ linkages also contains $\alpha-1,6$-linkages. Amylose is usually a minor component of starch (18-28\%).

Petroleum-derived polymers are not biodegradable and composites made from them pose a significant negative impact on the environment and ecosystem. Although starch is biodegradable and therefore represent an attractive potential substitute for petroleum-based polymers, they have serious drawback such as poor processability, mechanical properties and resistance to moisture. Starch lacks a defined melting point and decomposes over a temperature range. Consequently, it 
cannot in its native form be processed like petroleum-derived polymers. To be able to process starch, it must first be modified chemically or thermo-physically for starch plasticization (gelation). Chemical modification such as acetylation is associated with higher cost, negative environmental impact resulting from the use of chemicals and refining process. It also reduces its biodegradability.

In this study, we focused on starch's processability via plasticization. The process requires the presence of plasticizers (water and/ polyols, e.g. glycerol, sorbitol, etc.), heat and sometimes pressure. Plasticizers are low molecular weight substances that are incorporated into polymer matrix to increase the film flexibility and processability. They increase the free-volume or molecular mobility of polymers by reducing the hydrogen bonding between the polymer chains (Mathew et al 2002). Starch plasticization (gelation) occurs via destructionization of the starch molecular structure through the breaking of a hydrogen bond attended by partial depolymerization and loss of crystallinity. This can be done through several processes including extrusion; one of the most important methods for processing polymers. When starch is extruded, the combination of shear, temperature and plasticizer produce a thermoplastic material, plasticized starch (PLST). This is caused by the disruption of the native crystalline granular structure and plasticization (Gupta et al 2011).

Extruders fitted with rotary measurement mixers (torque rheometers) can be used to monitor gelation of a polymer. It allows the rheology form melts of the process to be studied. In this setup, two counter-rotating blades with non-symmetric profiles rotate at varying speeds in a heated mixing chamber. This creates intense heating and mixing of polymer and via shearing causes gelation of polymer (Tomaszewska et al 2004) to form melts. Time dependent changes in torque can be measured and used to characterize the gelation process and melt formation. In this process, the maximum point of the torque curve signifies the beginning of gelation to form melts and the minimum torque is illustrated by the free material that fills the chamber. The amount of torque also reflects the gelation-melt percolation thresholds and also the work required to effect gelation of the polymer and formation of melts. Thus, the amount of torque produced during mixing of polymers reflects the rheological behavior and processability of the melts (Afrifah et al 2010). The resulting plastographs provides information on the amount of torque, time, temperature and specific energy to bring about gelation of the polymer and formation of melts. 
The resistance of starch-based composites to moisture and improvement in mechanical properties can be achieved by either chemical modification of starch or inclusion of fillers as reinforcing agents (Bamberger et al. 1998). Chemical modification of starch is done through chemical reaction of starch hydroxyl functional groups with reactants such as adipic acid/acetic anhydride phosphorus oxychloride or sodium trimetaphosphate to form cross-linked starch (Spirion et al. 2011). However, such chemical modification reactions produce potential toxicity and diversity of by-products from the chemical reaction which might require purification and the additional cost or product. The use of fillers such as cellulose fibers will not add any additional cost to the product and will also help with the mechanical properties.

In this study, our approach was to include renewable polymers: lignin and pulp fibers. Although lignin contributes to improvement in water resistance of the composites, its hydrophobic character is incompatible with the hydrophilic character of starch. Thermodynamically, hydrophobic polymers are not miscible with starch and thus lead to poorer adhesion with starch. To compensate for this, recycled pulp fibers were added as fillers. Pulp fibers which contain cellulose and hemicelluloses are hydrophilic and therefore compatible with starch.

This study examined the effects of recycled pulp fibers and lignin as fillers on the processability of the starch matrix. The gelation of polymer matrices and its blend of with the other components to form melts during processing have been studied using Torque Rheometry (Matuana et al 2007 and Afrifah et al 2010).

\section{EXPERIMENTAL}

\subsection{Materials}

Two types of starch biopolymers used in this study, one contained 99\% Amylopectin and the other contained 25\% Amylose. Pulp, bleached and unbleached, was used as reinforcing agents in the starch composite. Bleached pulp was supplied by Fibrek Inc. (Fairmont, WV) and unbleached pulp was provided by Weyerhaeuser Inc. (Columbus, MS). The plasticizing agent, glycerol, was purchased from Fisher Scientific Inc. (Pittsburgh, PA). The Kraft lignin, Indulin ATC, was supplied by MeadWestvaco Inc. (Charleston, SC) and "Pure" lignin was provided by Pure Lignin Environmental Technology Inc. (Kelowna, British Columbia - Canada). 


\subsection{Methods}

This was a completely randomized fractional factorial design with three factors at two levels, starch (Amylose, Amylopectin), lignin (Kraft Lignin - Indulin ATC, "Pure" lignin) and pulp fiber (bleached, unbleached). Therefore, there were four different composites made and each composite was replicated three times. Concentration of plasticizer, glycerol, was kept at $30 \%$ wt/wt. The treatments without the replicates are shown in Table 1.

\subsection{Pre-Processing of Starch}

Starch samples and reagent grade glycerol from Fisher Scientific were used together to prepare the starch-polymer matrices. Starch was kept in oven at $50^{\circ} \mathrm{C}$ to keep moisture content down. Starch and glycerol, 30\% w/w of glycerol to starch, were premixed in polyethylene bags until a powder was obtained. The amount of fiber in the composite was calculated as a percentage of the total dry weight of starch plus glycerol. The use of $10 \% \mathrm{w} / \mathrm{w}$ cellulose fibers (bleached and unbleached) were added accordingly.

\subsection{Processability of starch}

Processability of starch in the presence of glycerol, pulp fiber and lignin was studied in a 60-ml electrically heated three-piece internal mixer/measuring (3:2 gear ratio) with roller style mixing blades (C.W. Brabender ${ }^{\circledR}$ Instruments Inc., South Hackensack, NJ) as described previously by Afrifah and Matuana (Afrifah et al 2010 and Matuana et al 2007). This mixer was powered by a 5.6 kilowatt (7.5 hp) Intelli-Torque Plasti-Corder Torque Rheometer ${ }^{\circledR}$ drive (C.W. Brabender ${ }^{\circledR}$ Instruments). The starch-glycerol-pulp fibers-lignin mixture (25 g) was loaded into the preheated chamber at $130^{\circ} \mathrm{C}$. The temperature throughout the process was maintained at this temperature. The rotors operated at $35 \mathrm{rpm}$ and the mixture was discharged after five minutes. A $5 \mathrm{~kg}$ dead weight was put on top of the mixer head throughout the experiments. The gelation and melt characteristics (time, temperature, torque and energy) were recorded by the Brabender® Mixer Program (WINMIX, version 3.2.11), and the data were analyzed by the Brabender ${ }^{\circledR}$ Data Correlation software (MIXCORR, version 2.0.10). All composites were run in triplicates to obtain average values for the gelation characteristics. 


\section{RESULTS AND DISCUSSION}

\subsection{Processability of Starch}

At the end of processing, dark-to-medium brown starch-lignin-pulp fibers pastes were obtained and collected. The processability of starch, lignin and pulp fibers as measured by the Brabender Rheometer and analyzed by the Brabender Data Correlation software (MIXCORR, version 2.10.10) (Matuana et al 2007) is shown in Figure 1. The processability is reflected by points A, $B, X$ and the area between B and X (Matuana et al 2007). During this process, starch gels and forms melts with the other components. Figure 7 is referred to as a Gelation-Melt curve and its interpretation is after Matuana (Matuana et al 2007). During processability, loading is given by Point A and Point B is a reflection of free material flow. Point X is caused by compaction and the onset of gelation as the material has at this point attained void-free state and has commenced to melt at the interface between the compacted material and the hot metal surface. Consequently, the portion between the loading point $\mathrm{A}$ and the Gelation point $\mathrm{X}$ is as the gelation time (Matuana et al 2007). Similarly, the temperature, torque and energy point $\mathrm{X}$ are also referred to as Gelation temperature, Gelation torque and Gelation energy, respectfully (Matuana et at 2007, Mohanty et al 2002, Rabinovitch et al 1982, Comeaux et al 1994, Chen et al 1995, Chen et al 1999).

The fractional factorial design used in this study is usually exploratory and has the primary advantage of reducing number of treatments by as much as half. As result, the interaction between some lignin and pulp fibers cannot be evaluated because they are confounded in the starch. Thus, this experimental design usually serves as an initial screening tool for identifying in a process factors that exert real influence on the response factor (Brereton 2003). Therefore, amount of information that can be derived from the experiment is reduced. In this study, the interaction between pulp fibers and lignin could not be determined.

Gelation characteristics correlated with type of starch; Amylose and Amylopectin and had great influence on processability. Amylose containing composites mixtures (\#1 and \#2) exhibited higher loadings (A), free material (B) and compaction and onset of gelation than amylopectin composites mixtures (\#3 and \#4). The processing parameters of amylose such as high gelation

temperature, torque and energy can be ascribed to its linear structure which is characterized by higher crystallinity. The gelation characteristics of the four composite mixtures are given in 
Table 1-2. Amylose containing composite mixtures (\# 1 and \# 2) was associated with higher gelation characteristics. The lowest gelation torques and energies were exhibited by composites \#3 and \#4 (Amylopectin starch). This can be attributed to the crystallinity melting temperature of the two starch composites. Amylopectin is the more crystalline structure of the two starches, so therefore would have the greater influence on such things as hardness, modulus, tensile and even stiffness, respectfully. 
Figure 6. Gelation-Melt Curves of Composite Mixtures

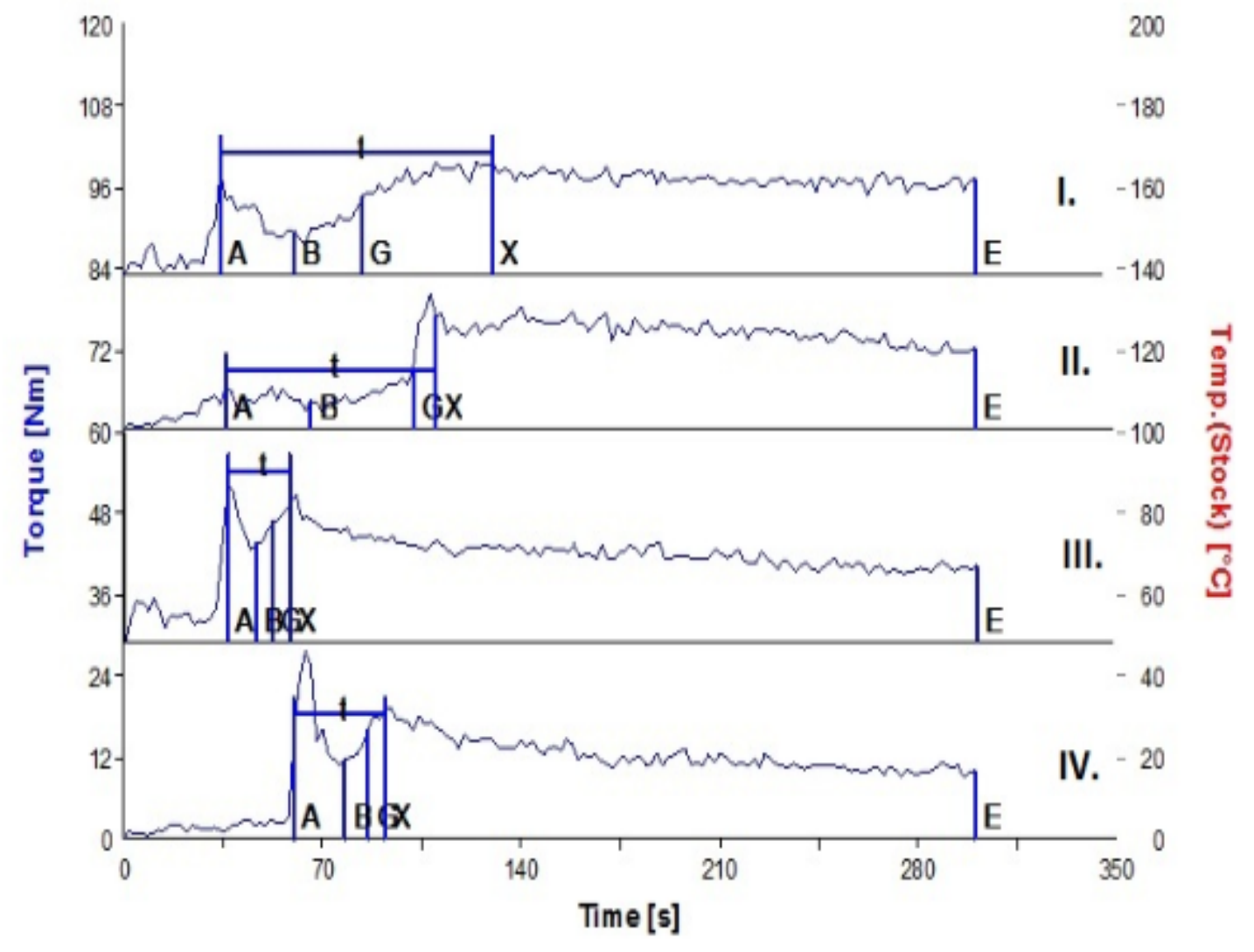


Table 1. Gelation-Melt Properties of Composite Mixtures

\begin{tabular}{l|c|c|c|c}
\hline & Time (s) & Temperature $\left({ }^{\circ} \mathrm{C}\right)$ & Torque $(\mathrm{N} \mathrm{m})$ & Energy (kN m) \\
\hline Composite \#1 & 300 & $143 \pm 1$ & $12 \pm 1$ & $12 \pm 1$ \\
\hline Composite \#2 & 300 & $142 \pm 2$ & $14 \pm 1$ & $12 \pm 2$ \\
\hline Composite \#3 & 300 & $140 \pm 1$ & $10 \pm 1$ & \\
\hline Composite \#4 & 300 & $138 \pm 2$ & $10 \pm 1$ & $9 \pm 1$ \\
\hline
\end{tabular}


Table 2. Composition of Composites Mixtures

\begin{tabular}{|c|c|c|c|c|c|c|c|}
\hline & \multicolumn{2}{|c|}{ Starch } & \multicolumn{2}{|c|}{ Lignin } & \multicolumn{2}{|c|}{ Cellulose Fibers } & \multirow[t]{2}{*}{ Glycerol } \\
\hline & Amylose & Amylopectin & Kraft Lignin & Pure Lignin & Unbleached & Bleached & \\
\hline Composite \#1 & $48 \% \mathrm{w} / \mathrm{w}$ & & & $12 \% \mathrm{w} / \mathrm{W}$ & & $10 \% \mathrm{w} / \mathrm{W}$ & $30 \% \mathrm{w} / \mathrm{w}$ \\
\hline Composite \#2 & $48 \% \mathrm{w} / \mathrm{w}$ & & $12 \% \mathrm{w} / \mathrm{w}$ & & $10 \% \mathrm{w} / \mathrm{w}$ & & $30 \% \mathrm{w} / \mathrm{w}$ \\
\hline Composite \#3 & & $48 \% \mathrm{w} / \mathrm{w}$ & $12 \% \mathrm{w} / \mathrm{w}$ & & & $10 \% \mathrm{w} / \mathrm{w}$ & $30 \% \mathrm{w} / \mathrm{w}$ \\
\hline Composite \#4 & & $48 \% \mathrm{w} / \mathrm{w}$ & & $12 \% \mathrm{w} / \mathrm{w}$ & $10 \% \mathrm{w} / \mathrm{W}$ & & $30 \% \mathrm{w} / \mathrm{w}$ \\
\hline
\end{tabular}

- Glycerol is kept constant at $30 \% \mathrm{w} / \mathrm{w}$

- Cellulose Fibers are at either 10\% w/w 


\section{CONCLUSIONS}

In this study, processability of starch, lignin and pulp fibers were evaluated using a Brabender ${ }^{\circledR}$ Torque Rheometer. The effects of lignin and pulp fibers were confounded within starch types due to the experimental design used. Processability was greatly influenced by type of starch. Gelation-melt characteristics of the four composite mixtures correlated with starch type. Amylose containing composites mixtures (\#1 and \#2) were associated with higher gelation-melt energies characteristics, while the Amylopectin composites mixtures (\#3 and \#4) were associated with the lowest gelation-melt torques and energies. 


\section{References}

1. Afrifah, K., Hickok, R. and Matuana, L. Polybutene as a matrix for wood plastics. Composites Science and Technology. 2010, 70, 167-172

2. Baumberger, S., Lapierre, C. and Monties, B. Utilization of Pine Kraft Lignin in Starch Composites: Impact of Structural Heterogeneity. J. Agric. Food Chem. 1998, 46, 2234-220.

3. Baumberger, S., Lapierre, C., Monties, B. and Della Valle, G. Use of kraft lignin as filler for starch films. Polymer Degradation and Stability. 1998, 59, 273-277.

4. Brereton, R. Chemometrics: data analysis for the laboratory and chemical plant. Wiley, 2003.

5. Chen, C., Wesson, R., Collier, J. and Lo, Y. J. Applied Polymer Science. 1995, 58, 1107.

6. Chen, C. and Lo, Y. J. Applied Polymer Science. 1999, 74, 699.

7. Comeaux, E., Chen, C., Collier, J. and Lo, Y. Polymer Bull. 1994, 33, 701.

8. Gupta, K. Starch based composites for packaging applications. In Handbook of Bioplastics and Biocomposites Engineering Applications. Ed: S. Pilla. New Jersey: Scrivener Publishing LLC/John Wiley \& Sons edition 2011, pp. 189-266.

9. Mathew, A. and Dufresne, A. Plasticized Waxy Maize Starch: Effect of Polyols and Relative Humidity on Material Properties. Biomacromolecules. 2002, 3 (5), 11011108.

10. Matuana, L. and Kim, J. Fusion Characteristics of Rigid PVC/Wood-Flour Composites by Torque Rheometry. Journal of Vinyl \& Additive Technology. 2007, $13,7-13$.

11. Mohanty, A., Misra, M. and Drzal, L. Sustainable Bio-Composites from Renewable Resources: Opportunities and Challenges in the Green Materials World. Journal of Polymers and the Environment. 2002, Vol. 10, Nos. 1/2, April 2002.

12. Newman, A. Glycerol. Cleveland: C.R.C. Press edition 1968.

13. Prachyayawarakorn, Sangnitiedj, P. and Boonspasith, P. 2010. Properties of thermoplastic rice starch composites reinforced by cotton fiber or low-density polyethylene. Carbohydrate Polymers. 2010, Vol. 81, 425-433. 
14. Rabinovitch, E. J. Vinyl Technology. 1982 4(2), 62.

15. Radley, J. Starch And Its Derivatives. London: Chapman \& Hall LTD edition 1943.

16. Sarkanen, K. and Ludwig, C. Lignins: Occurrence, Formation, Structure, and Reactions. New York: Wiley-Interscience edition 1971.

17. Smook, G. Handbook For Pulp \& Paper Technologists. Atlanta: TAPPI edition 1986.

18. Spiridon, I., Teaca, C., Bodirlau, R. Preparation and characterization of adipic acidmodified starch microparticles/plasticized starch composite films reinforced by lignin. J. Material Science. 2011, 46, 3241-3251.

19. Tomaszewska, J., Sterzynski, T. and Piszczek, K. Rigid poly(vinyl chloride)(PVC) gelation in the Brabender (Mixer. I. Equilibrium state between sliding, breaking and gelation of PVC. Journal of Applied Polymer Science. 2004, 93, 966-971. 


\title{
5 MECHANICAL AND CHEMICAL PROPERTIES OF STARCH BIO-COMPOSITES REINFORCED WITH PULP FIBERS
}

\author{
C.A. Collins II, L. M. Matuana and B. Dawson-Andoh
}

\begin{abstract}
Four plasticized starch bio-composites melts containing pulp fibers and lignin were produced. Glycerol was used as the plasticizing agent. Higher mechanical properties were associated with starch bio-composites containing amylopectin. Composites \#1 and \#4 exhibited the highest water absorption and Composites \#2 and \#3 exhibited the lowest water absorption. The type of lignin used as filler made a greater contribution of the hydrophobicity of the starch composites. Moisture content of all starch composites was similar between all starch-lignin composites. Fourier Transform Infrared analysis of composites showed the absence of any new discernible chemical bonds. Potential new hydrogen bonds formed between starch and fillers could not be detected. Bio-composites containing amylopectin exhibited the highest glass transition. Thermal degradation patterns for all starch composites were different. Mass loss below $100^{\circ} \mathrm{C}$ was associated with loss of water. Loss of glycerol commenced around $200^{\circ} \mathrm{C}$ and its thermal degradation was completed around $300^{\circ} \mathrm{C}$. Thermal degradation of pulp fiber occurred in two stages: $230^{\circ} \mathrm{C}$ and $230-390^{\circ} \mathrm{C}$ where the largest mass loss occurred. Scanning electron microscope showed that pulp fibers were not well dispersed and aligned within the composites.
\end{abstract}

\section{INTRODUCTION}

Composites made from petroleum-derived polymers have attracted increasing public concern because these products persist in the environment for extended periods at the end of their service life. Bio-composites represent potential alternatives to fossil-derived polymer composites. Biocomposites like all composites consist of two major components; matrix and filler (s). Both matrix and filler (s) can be biodegradable. Three major types of biodegradable polymers are recognized (Averous et al 2004 and Flieger et al 2003). They are: (1) polymers from agriculture materials (agro-polymers, e.g. polysaccharides), (2) polymers obtained via fermentation of agromaterials or genetically modifying plants (e.g. polyhydroxyalkanoate) and (3) synthesis of polymers from agro-based feed stocks (e.g. polylactic acid). Agro-based polysaccharide polymers include starch, cellulose, lignin, hemicelluloses and chitin. Starch has attracted considerable attention because of their availability and biodegradability. Starch has been used as 
fillers in petroleum-derived polymer matrices. However, these composites have exhibited poor degradability in after service disposed systems.

Starch is used in the manufacture of composites in four major ways. In low amounts (10-20\% $\mathrm{wt} / \mathrm{v}$ ), starch is used as fillers in composites where the matrix is a petroleum-derived polymer (Flieger et al. 2003). Composites containing this low amount of starch exhibit enhanced disintegration in nature after service because bio-deteriorating agents metabolize the starch and create voids in the composites. This finally leads to the breakdown of the composites. However, such composites cannot be deemed as biodegradable. Starch is also used at two higher levels, 40$60 \%(\mathrm{wt} / \mathrm{v})$ and $90 \%(\mathrm{wt} / \mathrm{v})$. At these levels, starch is used as the matrix. However, starch cannot be processed as petroleum-derived polymers. To enable this, starch is first converted to plasticized starch via the use of plasticizers. Plasticizers are usually water or polyhydroxy compounds such as glycerol, sorbitol, sugars and ethanolamine.

However, starch bio-composites have significant drawbacks such as sensitivity to humidity, moisture and poor mechanical properties. Additionally, starch cannot be processed like other petroleum-derived polymers. Starch when used as a matrix is converted to thermoplastic form (plasticized starch - PLS) plasticized through the use of a plasticizer. In this process, hydrogen bonds between starch molecules are broken and simultaneously reformed between starch and the plasticizer (Prachyayawarakorn et al 2010). Plasticized starch is more flexible because of the reduction of bonds and lends it's more easily to processing like petroleum-derived polymers. Like petroleum-derived polymers, PLS can be compress-molded, injection-molded or extruded. Starch $(100 \% \mathrm{wt} / \mathrm{v})$ can be converted to foams using water steam or via a compression-explosion process (Flieger et al. 2003). Foamed starch products are anti-static, insulating and shock absorbing and can replace petroleum-derived products such polystyrene foam or thin walled products such as trays and disposable dishes. Starch foam products like the medium and high level starch-based bio-composites are truly biodegradable and will degrade in a short period in the environment at the end of their service life.

The weaknesses of the starch-biocomposites can be addressed by chemical modification of starch by cross-linking of the polydroxy groups on the starch macro-molecule. However, this process is expensive and may negative environmental impacts because of the need to dispose of chemicals used and by-products of the reactions. Further, the primary products may require refining thus adding to the overall cost of the product. Another approach to enhance the properties starch 
composites is to reinforce it with fillers that will improve its resistance to moisture and improve its mechanical properties. These fillers can be agro-based polymers or petroleum-derived polymers. The additional advantage of the use of agro-based polymers as fillers is that it will make the bio-composite biodegradable.

Thus, this study examined the effect of two agro-based polymers, pulp fiber and lignin, on the mechanical properties and resistance to moisture. The impacts of these fillers on some chemical properties were also evaluated. Lignin is a waste by-product of the pulp and paper industry and is readily available.

\section{EXPERIMENTAL}

\subsection{Materials}

This study employed two types of starch biopolymers, one contained $99 \%$ amylopectin and the other contained $25 \%$ amylose. Two types of pulp, bleached and unbleached, were used as reinforcing agents. Bleached pulp was provided by Fibrek Inc. (Fairmont, WV) and unbleached pulp was supplied by Weyerhaeuser Inc. (Columbus, MS). The plasticizing agent, glycerol, was procured from Fisher Scientific Inc. (Pittsburgh, PA). Kraft lignin - Indulin ATC was supplied by MeadWestvaco Inc. (Charleston, SC) and "Pure" lignin was supplied by Pure Lignin Environmental Technology Inc. (Kelowna, BC, Canada).

\subsection{Methods}

\subsubsection{Experimental design}

This was a completely randomized fractional factorial design with three factors at two levels, starch (amylose, amylopectin), lignin (Kraft lignin - Indulin ATC, "Pure" lignin) and pulp fiber (bleached, unbleached). Therefore, there were four different composites made and each composite was replicated three times. Concentration of plasticizer, glycerol, was kept at $30 \%$ wt/wt. The treatments without the replicates are shown in Table 3.

\subsubsection{Pre-Processing of Matrix}

Starch was pre-processed by mixing starch and glycerol. This mixture was placed in an oven at $50^{\circ} \mathrm{C}$ to maintain low moisture content. Starch and glycerol, $30 \% \mathrm{w} / \mathrm{w}$ of glycerol to starch, were pre-mixed in polyethylene bags until a powder was obtained. The amount of fiber in the 
composite was calculated as a percentage of the total dry weight of starch plus glycerol. The use of $10 \% \mathrm{w} / \mathrm{w}$ pulp fibers (bleached and unbleached) were added accordingly.

\subsubsection{Procession of starch}

Starch, lignin and pulp fibers were processed in a 60-ml electronically heated three-piece internal mixer/measuring head (3:2 gear ratio) with roller style mixing blades. The mixture was loaded into the pre-heated chamber at $130^{\circ} \mathrm{C}$. The rotors operated at $35 \mathrm{rpm}$ and the mixture was discharged after five minutes as described previously (page 25). A $5 \mathrm{~kg}$ dead weight was put on top of the mixer head throughout the experiments. All composites were run in triplicates to obtain average values for the gelation characteristics. A dark brown paste obtained was compress-molded.

\subsubsection{Compression Molding of plasticized starch}

Composite mixtures were placed into moldings and pressed into the two desired shapes, dogbones and bars, following the ASTM-D4703-10A. The composite mixtures were placed in an oven at $50^{\circ} \mathrm{C}$ for at least 24 hours and pressed using a Carver Hydraulic Laboratory Press (Model 12-10HC) with safety shield. Used Reynolds Wrap $\subset$ Non-Stick on the pressing molds and 770NC solution to keep the samples from sticking to the molds; test samples were pressed in molds at $130^{\circ} \mathrm{C}$ and 20,000 psi for five minutes. All dog-bones (Type V, thickness of 3.2 millimeters and length of 2.5 inches) and bars (Depth $=1.6$ millimeters, Width $=1$ inch, Length $=4$ inches) were individually weighed and counted.

\subsubsection{Mechanical Testing}

The TA-HD $i$ Texture Analyzer (Texture Technologies Corporation, Scarsdale, NY 10583) with different attachments were used to measure the tensile (tensile grips), flexural (3-point bend) and shear properties of the four different starch-lignin composites reinforced with pulp fibers following ASTM-D638-10 with the following settings: Pre-test: $2 \mathrm{~mm} / \mathrm{s}$, Test: $1 \mathrm{~mm} / \mathrm{s}$, Post-test: $2 \mathrm{~mm} / \mathrm{s}$, Rupture Test Distance: $4 \mathrm{~mm}$, Distance $15 \mathrm{~mm}$, Force: 100g, Time $5 \mathrm{sec}$, Load Cell: $250 \mathrm{~kg}$ and temperature: $25^{\circ} \mathrm{C}$ and ASTM-D790-10 with the following settings: Pre-test: $2 \mathrm{~mm} / \mathrm{s}$, Test: $1 \mathrm{~mm} / \mathrm{s}$, Post-test: $2 \mathrm{~mm} / \mathrm{s}$, Distance $23 \mathrm{~mm}$; for tensile and flexural properties, respectfully. Measurements were taken in triplicates. 


\subsubsection{Moisture Content}

This study is to determine the moisture content of the four different starch-lignin composites according to ASTM D4442-07. Dogbone (Type V) samples of the four different composites were weighed, and then put into the oven at $103 \pm 5^{\circ} \mathrm{C}$ for $24 \mathrm{~h}$. The samples were weighed again after being taken out. The moisture content rate (MC) took the following formulation:

$$
\mathrm{MC} \%=\left[\left(\mathrm{W}_{\mathrm{i}}-\mathrm{W}_{\mathrm{f}}\right) / \mathrm{W}_{\mathrm{i}}\right] \times 100
$$

$\mathrm{W}_{\mathrm{i}}$ was the initial mass of the sample, $\mathrm{g}$;

$\mathrm{W}_{\mathrm{f}}$ was the final mass of the sample, $\mathrm{g}$.

Measurements were taken in triplicates.

\subsubsection{Water Absorption}

Water absorption of the starch bio-composites was determined as per ASTM D570-98 for both 2hours and 24-hours. Water absorption test is used to determine the amount of water absorbed under the specified conditions. The bar (depth $=1.6$ millimeters, width $=1$ inch, Length $=4$ inches) samples of the four different starch-lignin composites were weighed before and after the water absorption process. The total percentage of weight is labeled as $\mathrm{W}_{\mathrm{a}}$, which refer to the percentage of water absorbed.

$$
\mathrm{W}_{\mathrm{a}} \%=\left[\left(\mathrm{W}_{\mathrm{i}}-\mathrm{W}_{\mathrm{f}}\right) / \mathrm{W}_{\mathrm{i}}\right] \times 100
$$

$\mathrm{W}_{\mathrm{i}}$ was the initial mass of the sample, $\mathrm{g}$;

$\mathrm{W}_{\mathrm{f}}$ was the final mass of the sample, $\mathrm{g}$.

Measurements were taken in triplicates.

\subsubsection{Fourier transform infrared spectra of composites}

Fourier Transform Infrared spectra of the four starch bio-composites were recorded on a Perkin Elmer 100 FT-IR Spectrometer at a resolution of $4 \mathrm{~cm}^{-1}$. The scanning range was 400 to 4000 $\mathrm{cm}^{-1}$. 


\subsubsection{Differential Scanning Calorimetry of Composites}

Thermal properties of the starch bio-composites were determined using a TA Differential Scanning Calorimeter Q20, at a rate of $10^{\circ} \mathrm{C} / \mathrm{min}$ from ambient temperature to $500^{\circ} \mathrm{C}$. Approximately $10 \mathrm{mg}$ specimens of each starch bio-composite in aluminum pans were used in this study. All four samples of approximately $10 \mathrm{mg}-30 \mathrm{mg}$ were placed in aluminum pans. Glass transition temperatures were scanned from -170 to $40{ }^{\circ} \mathrm{C}$ under a nitrogen flow of $50 \mathrm{ml} / \mathrm{min}$.

\subsubsection{Thermogravimetric analysis of Composites}

Thermal degradation properties of the four composites were determined by thermogravimetric analysis (TGA) using a TA Instruments Q50. $12 \mathrm{mg}-50 \mathrm{mg}$ per specimen was used. Each specimen was heated from ambient temperature to $500^{\circ} \mathrm{C}$ at a heating rate of $10^{\circ} \mathrm{C} / \mathrm{min}$ in a nitrogen atmosphere.

\subsubsection{Scanning Electron Microscopy of Composites}

The morphology of surface of original starch bio-composite specimens and surfaces of mechanically fractured specimens were studied using a Hitachi S-4700 FE-SEM Field-Emission Scanning Electron microscope at accelerating rate of $12 \mathrm{kV}$. The samples were placed on aluminum stubs using double face adhesive tapes and coated with gold.

\section{Results and discussions}

Tensile properties of the four starch bio-composites are presented in Table 4. For all treatments, Stress, Strain and Modulus of Elasticity were not statistically significant from each other. The average Force for Composite \#1 and \#3 were not statistically significantly different from each other. Composite \#4 (amylopectin starch) had the highest average Force, Modulus of Rupture and the lowest Elongation at Break. For composites \#1 and \#3, Modulus of Rupture was not statistically different from each other. Mechanical properties for bending are reported in Table 5. For bending properties, except for average Gradient and Modulus of Elasticity, all properties for all composites were not statistically significantly different from each other. Composite \# 3 (amylopectin starch) had the highest average Gradient, Modulus of Elasticity and lowest Elongation at Break. Composites \#1 and \#2 contained amylose while Composites \#3 and \#4 
contained amylopectin. However, the composites also contained different types of lignin and different types of pulp fibers. The two different types of starch bio-composites contained different types of lignin which may have exerted different effects on the mechanical properties of the composites. However, since a fractional factorial design was employed their interaction is confounded with the starch factor.

On the basis of water absorption (Table 6), the starch composites could be placed in two groups. Composites \#1 and \#4 exhibited the highest water absorption and Composites \#2 and \#3 exhibited the lowest water absorption. The differences between these composites were the fillers that were used. Therefore, difference in water absorption could be ascribed to their lignin content. Composites \#2 and \#3 contained Kraft lignin - Indulin ATC and appeared to make greater contribution of the hydrophobicity of the starch composite, while Composites \#1 and \#4 contained "Pure" lignin. Moisture content of all starch composites ranged from 16\% - 17\%.

Fourier Transform Infrared Spectra of the four starch composites show no discernible presence of new chemical bonds (Figure 7); FTIR spectra for all starch composites were similar. Differential scanning calorimetry (DSC) is used to determine thermal behavior of materials (Aval et al. 2010). In this study, DSC analysis showed that the starch composites could be placed in two different groups on the basis of their glass transition temperature (Tg). The group with the lower Tg contained amylose while the second starch group (Composites \#3 and \#4) contained amylopectin. The higher $\mathrm{Tg}$ for the amylopectin starch group is due to its crystalline nature and fillers. Thermal stability of polymers and composites can be studied using thermogravimetric analysis (TGA). Degradation of wood pulp occurs in two stages. Initial degradation of wood pulp commences at $230^{\circ} \mathrm{C}$ (minimum mass weight loss, approximately $6 \%$ ). The second stage which is associated with largest mass loss $(76 \%)$ occurred in the $230-390^{\circ} \mathrm{C}$ temperature range. Below $100^{\circ} \mathrm{C}$, mass loss was primarily due to water (Yunos et al 2011). Evaporation of glycerol commences around $200^{\circ} \mathrm{C}$ and its degradation was completed around $300^{\circ} \mathrm{C}$. Behavior of the four starch bio-composites differed from each starch group (amylose and amylopectin), a reflection of the differences in their composition.

Scanning electron micrographs of the starch bio-composites showed smooth surfaces whilst others were characterized by globule like substances which may be lignin (Figures 8-15). Fractured surfaces demonstrated that pulp fibers were ribbon like and curled and not aligned within the bio-composite. Alignment of pulp fibers significantly contributes to its mechanical 
properties. It is thus suggested that mechanical properties of starch bio-composites can be enhanced by the use of shorter fibers which should be aligned; pulp fibers also appeared located in the core of the matrix.

\section{Conclusion}

The mechanical and chemical properties of four plasticized starch bio-composites were evaluated. Starch was plasticized using glycerol. Pulp fibers (bleached and unbleached) and lignin (Kraft lignin - Indulin ATC, "Pure” lignin) were used as fillers. Composites \#4 which contained amylopectin starch, unbleached pulp fibers and "Pure" lignin had the highest average Force, Modulus of Rupture and the lowest Elongation at Break. Composite \#3 (amylopectin starch) had the highest average Gradient, Modulus of Elasticity and lowest Elongation at Break. Composites \#1 and \#4 exhibited the highest water absorption and Composites \#2 and \#3 exhibited the lowest water absorption; the type of lignin used as filler made a greater contribution of the hydrophobicity of the starch composites. Moisture content of all starch composites was similar (16\% - 17\%). Fourier Transform Infrared analysis of composites showed the absence of any discernible chemical bonds. Bio-composites containing amylopectin exhibited the highest glass transition due to its crystallinity. Thermal degradation patterns for all starch composites were different. Mass loss below $100{ }^{0} \mathrm{C}$ was associated with loss of water. Loss of glycerol commenced around $200^{\circ} \mathrm{C}$ and its thermal degradation was completed around $300{ }^{\circ} \mathrm{C}$. Thermal degradation of pulp fiber occurred in two stages: $230^{\circ} \mathrm{C}$ and $230-390^{\circ} \mathrm{C}$ where the largest mass loss occurred. Scanning electron microscope showed that pulp fibers were not well dispersed and aligned within the composites. 
Table 3. Composition of Composite Mixtures

\begin{tabular}{|c|c|c|c|c|c|c|c|}
\hline & \multicolumn{2}{|c|}{ Starch } & \multicolumn{2}{|c|}{ Lignin } & \multicolumn{2}{|c|}{ Cellulose Fibers } & \multirow[t]{2}{*}{ Glycerol } \\
\hline & Amylose & Amylopectin & Kraft Lignin & Pure Lignin & Unbleached & Bleached & \\
\hline Composite \#1 & $48 \% \mathrm{w} / \mathrm{w}$ & & & $12 \% \mathrm{w} / \mathrm{W}$ & & $10 \% \mathrm{w} / \mathrm{w}$ & $30 \% \mathrm{w} / \mathrm{w}$ \\
\hline Composite \#2 & $48 \% \mathrm{w} / \mathrm{w}$ & & $12 \% \mathrm{w} / \mathrm{w}$ & & $10 \% \mathrm{w} / \mathrm{w}$ & & $30 \% \mathrm{w} / \mathrm{w}$ \\
\hline Composite \#3 & & $48 \% \mathrm{w} / \mathrm{w}$ & $12 \% \mathrm{w} / \mathrm{w}$ & & & $10 \% \mathrm{w} / \mathrm{w}$ & $30 \% \mathrm{w} / \mathrm{w}$ \\
\hline Composite \#4 & & $48 \% \mathrm{w} / \mathrm{w}$ & & $12 \% \mathrm{w} / \mathrm{w}$ & $10 \% \mathrm{w} / \mathrm{w}$ & & $30 \% \mathrm{w} / \mathrm{w}$ \\
\hline
\end{tabular}

- Glycerol is kept constant at 30\% w/w

- Cellulose Fibers are at either 10\% w/w 
Table 4. Mechanical Properties of Composites - Tensile

\begin{tabular}{c|c|c|c|c|c|c}
\hline & $\begin{array}{c}\text { Average } \\
\text { Force } \\
(\mathrm{lbs})\end{array}$ & $\begin{array}{c}\text { Stress } \\
\left(\mathrm{lbs} / \mathrm{in}^{2}\right)\end{array}$ & $\begin{array}{c}\text { Strain } \\
(\mathrm{in})\end{array}$ & $\begin{array}{c}\text { MOR }^{*} \\
(\mathrm{MPa})\end{array}$ & $\begin{array}{c}\text { MOE } \\
(\mathrm{GPa})\end{array}$ & $\begin{array}{c}\text { Elongation } \\
\text { at Break } \\
(\%)\end{array}$ \\
\hline $\begin{array}{c}\text { Composite } \\
\# 1\end{array}$ & $1.69^{\mathrm{ab}}$ & $.676^{\mathrm{a}}$ & $.168^{\mathrm{a}}$ & $.441^{\mathrm{a}}$ & $5.32 \times 10^{-5 \mathrm{a}}$ & 42 \\
\hline $\begin{array}{c}\text { Composite } \\
\# 2\end{array}$ & $1.27^{\mathrm{a}}$ & $.509^{\mathrm{a}}$ & $.125^{\mathrm{a}}$ & $.332^{\mathrm{a}}$ & $8.90 \times 10^{-5 \mathrm{a}}$ & 31 \\
\hline $\begin{array}{c}\text { Composite } \\
\# 3\end{array}$ & $1.69^{\mathrm{ab}}$ & $.676^{\mathrm{a}}$ & $.187^{\mathrm{a}}$ & $.441^{\mathrm{a}}$ & $6.54 \times 10^{-5 \mathrm{a}}$ & 47 \\
\hline $\begin{array}{c}\text { Composite } \\
\# 4\end{array}$ & $2.23^{\mathrm{c}}$ & $.891^{\mathrm{b}}$ & $.138^{\mathrm{a}}$ & $.581^{\mathrm{b}}$ & $8.87 \times 10^{-5 \mathrm{a}}$ & 34 \\
\hline
\end{tabular}

*Treatments with the same letter are not statistically different at $\mathrm{p}<0.05$ 
Table 5. Bending Properties of Starch Composites

\begin{tabular}{|c|c|c|c|c|c|c|c|}
\hline & $\begin{array}{c}\text { Average }^{*} \\
\text { Force } \\
(\mathrm{lbs})\end{array}$ & $\begin{array}{c}\text { Average } \\
\text { Gradient } \\
(\mathrm{lbs} / \mathrm{in})\end{array}$ & $\begin{array}{c}\text { Stress } \\
\left(\mathrm{lbs} / \mathrm{in}^{2}\right)\end{array}$ & $\begin{array}{c}\text { Strain } \\
(\mathrm{in})\end{array}$ & $\begin{array}{c}\text { MOR }^{*} \\
(\mathrm{MPa})\end{array}$ & $\begin{array}{c}\text { MOE } \\
(\mathrm{GPa})\end{array}$ & $\begin{array}{c}\text { Elongation } \\
\text { at Break } \\
(\%)\end{array}$ \\
\hline $\begin{array}{c}\text { Composite } \\
\# 1\end{array}$ & $.476^{\mathrm{a}}$ & $1.5^{\mathrm{a}}$ & $.119^{\mathrm{a}}$ & $.113^{\mathrm{a}}$ & $1.12^{\mathrm{a}}$ & $7.79 \times 10^{-6 \mathrm{a}}$ & 45 \\
\hline $\begin{array}{c}\text { Composite } \\
\# 2\end{array}$ & $1.04^{\mathrm{a}}$ & $3.8^{\mathrm{bc}}$ & $.259^{\mathrm{a}}$ & $.101^{\mathrm{a}}$ & $2.45^{\mathrm{a}}$ & $1.75 \times 10^{-5 \mathrm{bc}}$ & 40 \\
\hline $\begin{array}{c}\text { Composite } \\
\# 3\end{array}$ & $1.14^{\mathrm{a}}$ & $4.4^{\mathrm{c}}$ & $.286^{\mathrm{a}}$ & $.084^{\mathrm{a}}$ & $2.70^{\mathrm{a}}$ & $2.38 \times 10^{-5 \mathrm{c}}$ & 34 \\
\hline $\begin{array}{c}\text { Composite } \\
\# 4\end{array}$ & $.941^{\mathrm{a}}$ & $2.5^{\mathrm{ab}}$ & $.235^{\mathrm{a}}$ & $.124^{\mathrm{a}}$ & $2.22^{\mathrm{a}}$ & $1.31 \times 10^{-5 \mathrm{ab}}$ & 50 \\
\hline
\end{tabular}

${ }^{*}$ Treatments with the same letter are not statistically different at $\mathrm{p}<0.05$ 
Table 6. Water Absorption of Composites

\begin{tabular}{|c|c|c|}
\hline & $\begin{array}{c}\text { Water } \\
\text { Absorption } \\
\text { 2-Hours } \\
(\%)\end{array}$ & $\begin{array}{c}\text { Water } \\
\text { Absorption } \\
\text { 24-Hours } \\
(\%)\end{array}$ \\
\hline Composite \#1 & $44 \pm 6$ & $42 \pm 6$ \\
\hline Composite \#2 & $28 \pm 1$ & $27 \pm 1$ \\
\hline Composite \#3 & $25 \pm 1$ & $23 \pm 1$ \\
\hline Composite \#4 & $35 \pm 3$ & $33 \pm 2$ \\
\hline
\end{tabular}


Figure 7. Fourier Transform Infrared Spectra of Starch Composites

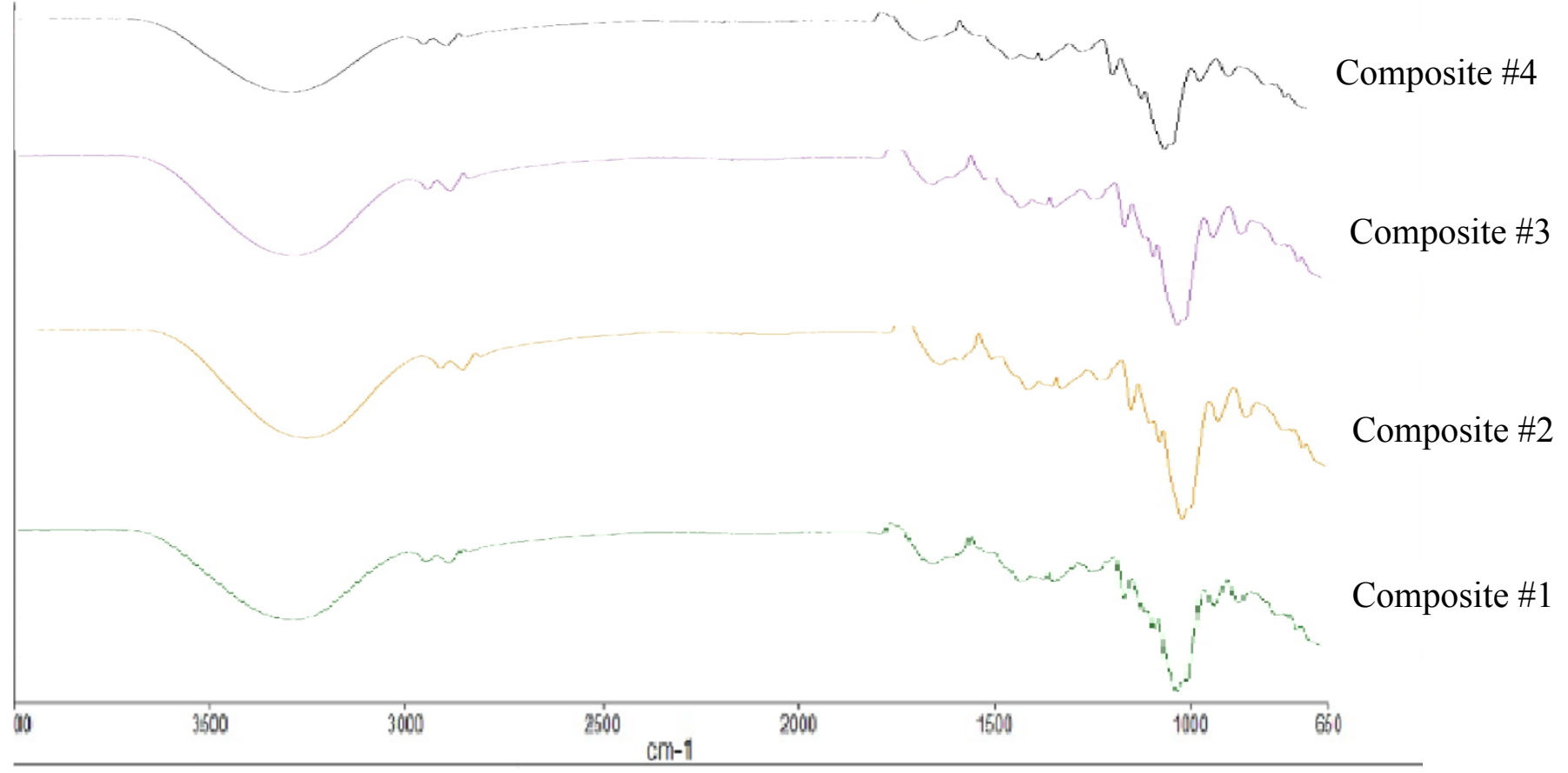


Table 7. Differential Scanning Calorimetry of Composites

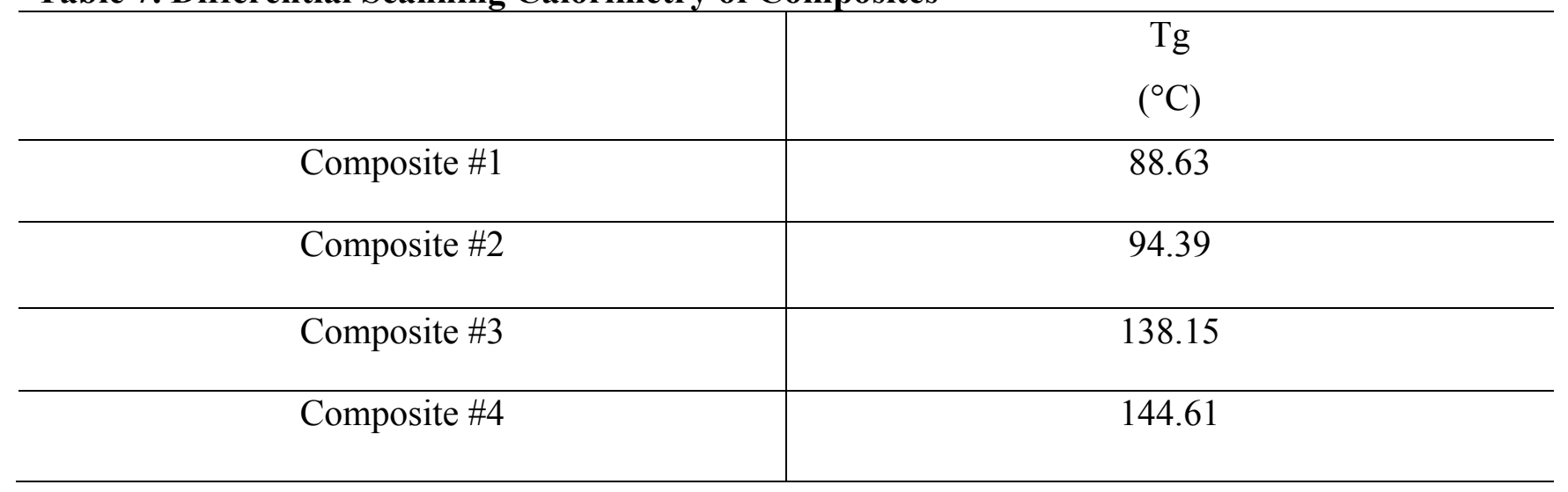


Table 8. Thermogravimetric Analysis of Composites

\begin{tabular}{|c|c|c|}
\hline & $\begin{array}{c}\text { Temperature at Major Peak } \\
\qquad\left({ }^{\circ} \mathrm{C}\right)\end{array}$ & $\begin{array}{c}\text { Percent Weight Change } \\
(\%)\end{array}$ \\
\hline \multirow[t]{4}{*}{ Composite \#1 } & 48.12 & 10.37 \\
\hline & 169.84 & 17.50 \\
\hline & \multirow[t]{2}{*}{292.52} & 43.45 \\
\hline & & 13.87 \\
\hline \multirow[t]{4}{*}{ Composite \#2 } & 196.71 & \multirow[t]{2}{*}{17.49} \\
\hline & \multirow[t]{2}{*}{295.72} & \\
\hline & & \multirow[t]{2}{*}{46.58} \\
\hline & 345.54 & \\
\hline \multirow[t]{3}{*}{ Composite \#3 } & 77.52 & 9.220 \\
\hline & 180.94 & 13.43 \\
\hline & 328.51 & 57.15 \\
\hline \multirow[t]{3}{*}{ Composite \#4 } & 92.65 & 6.737 \\
\hline & 289.42 & 50.31 \\
\hline & 333.93 & 16.16 \\
\hline
\end{tabular}




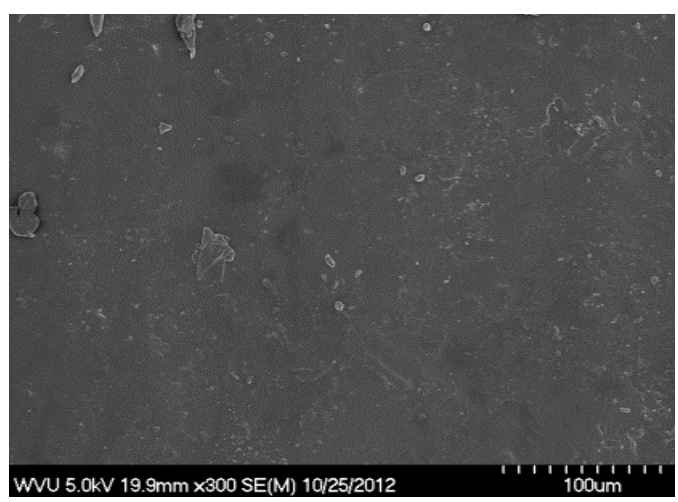

Figure 8. 300x Top View of Composite \#1

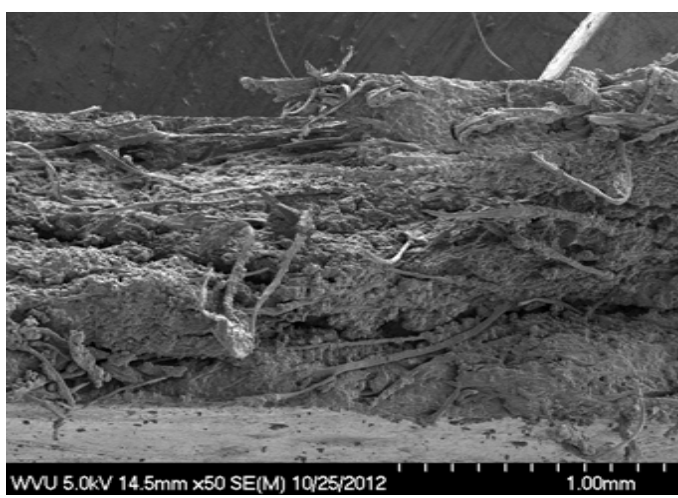

Figure 9. 50x Cross-Section View of Composite \#1 


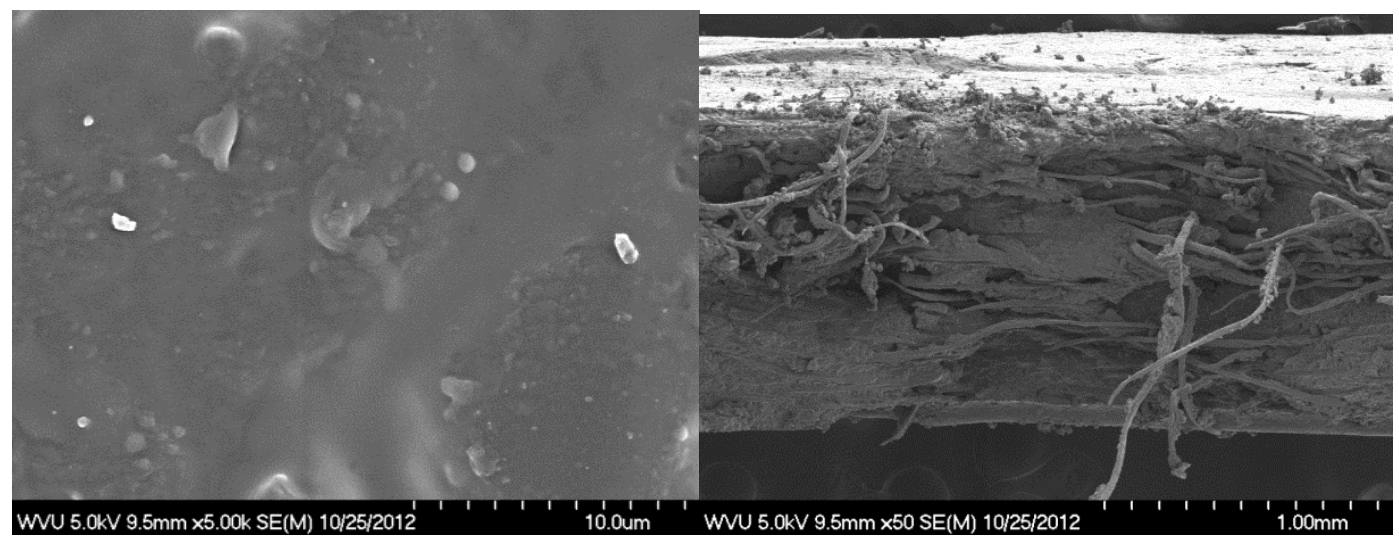

Figure 10. 5000x Top View of Composite \#2
Figure 11. 50x Cross-Section View of Composite \#2 


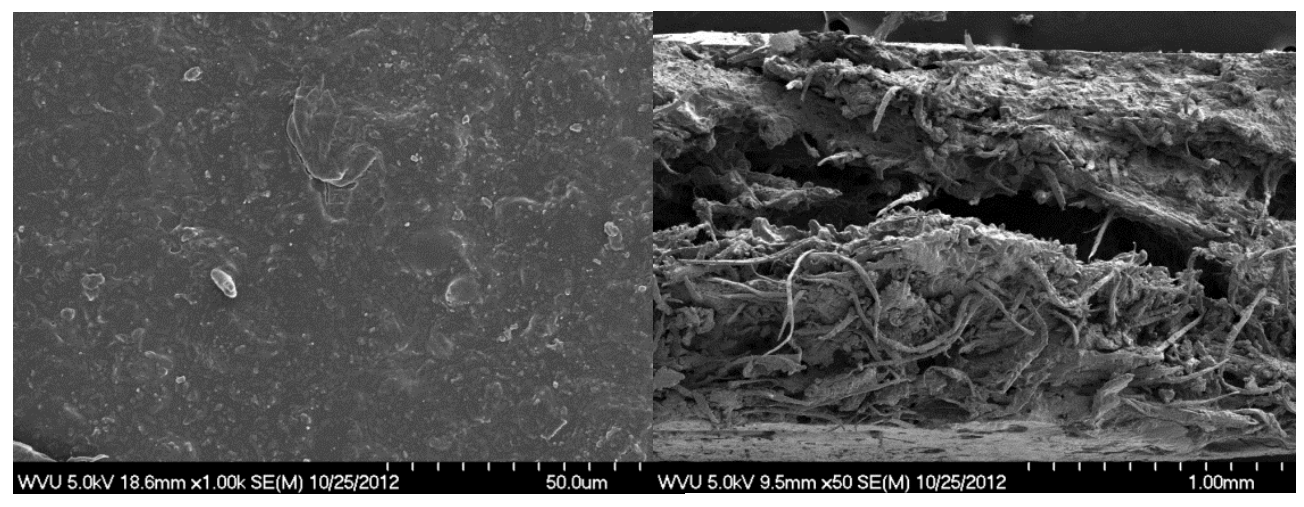

Figure 12. 1000x Top View of Composite

Figure 13. 50x Cross-Section View of \#3 Composite \#3 


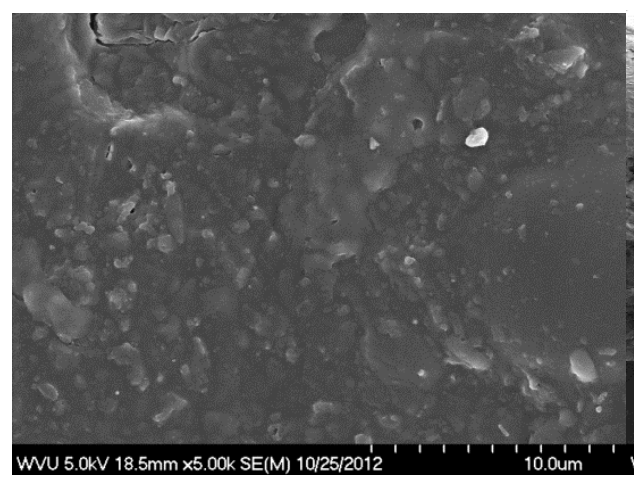

Figure 14. 5000x Top View of Combosite \#4

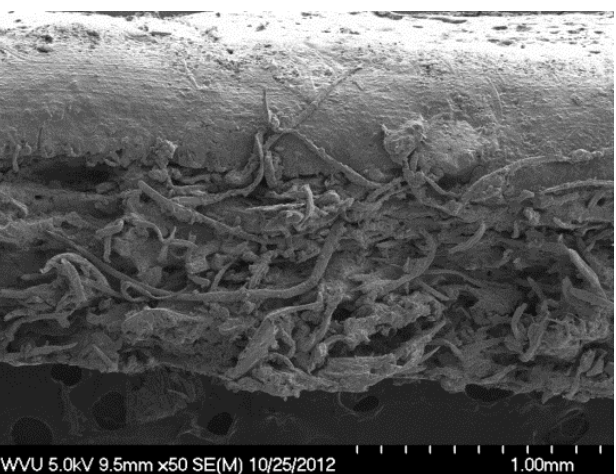

Figure 15. 50x Cross-Section View of Composite \#4 


\section{References}

1. Albertsson, A. and Karlsson, S. Chemistry and Technology of Biodegradable Polymers. Blackie, Glasgow: 1994.

2. Aval, S., Ghosh, R. and Sein, M. Thermal properties and spectral characterization of wood pulp reinforced bio-composite. J. Therm. Anal. Calorim. 2010, Vol. 99. 696701.

3. Averous, L. Biodegradable Multiphase Systems Based on Plasticized Starch: A Review. Journal of Macromolecular Science. Part C - Polymer Review. 2004, Vol. C44, No. 3, pp. 231-274.

4. Baumberger, S., Lapierre, C. and Monties, B. Utilization of Pine Kraft Lignin in Starch Composites: Impact of Structural Heterogeneity. J. Agric. Food Chem. 1998, 46, 2234-220.

5. Baumberger, S., Lapierre, C., Monties, B. and Della Valle, G. Use of kraft lignin as filler for starch films. Polymer Degradation and Stability. 1998, 59, 273-277.

6. Flieger, M., Kantorova, M., Prell, A., Řezanka, T. and Votruba, J. Biodegradable plastics from renewable sources. Folia microbiologica. 2003, Vol. 48, 27-44.

7. Hamid SH, Amin MB, Maadhah, AG. Handbook of Polymer Degradation. Marcel Dekker, New York, Hong Kong: 1992.

8. Lu, D., Xiao, C., Xu, S. Starch-based completely biodegradable polymer materials. eXPRESS Polymer Letters. 2009, Vol. 3, No. 6, 366-375.

9. Newman, A. Glycerol. Cleveland: C.R.C. Press edition 1968.

10. Prachyayawarakorn, Sangnitiedj, P. and Boonspasith, P. 2010. Properties of thermoplastic rice starch composites reinforced by cotton fiber or low-density polyethylene. Carbohydrate Polymers. 2010, Vol. 81, 425-433.

11. Radley, J. Starch And Its Derivatives. London: Chapman \& Hall LTD edition 1943.

12. Sarkanen, K. and Ludwig, C. Lignins: Occurrence, Formation, Structure, and Reactions. New York: Wiley-Interscience edition 1971.

13. Smook, G. Handbook For Pulp \& Paper Technologists. Atlanta: TAPPI edition 1986. 
14. Spiridon, I., Teaca, C., Bodirlau, R. Preparation and characterization of adipic acidmodified starch microparticles/plasticized starch composite films reinforced by lignin. J. Material Science. 2011, 46, 3241-3251.

15. Yu, L., Dean, K. and Li, L. Polymer blends and composites from renewable resources. Progress in Polymer Science. 2006, 31, 576-602.

16. Yunos, M. and Rahman, W. Effect of Glycerol on Performance Rice Straw/Starch Based Polymer Journal of Applied Sciences. 2011, Vol. 11 (3), 2456-2459. 


\title{
6 BIODEGRADATION OF STARCH-LIGNIN BIOCOMPOSITES REINFORCED WITH PULP FIBERS
}

\author{
C.A. Collins II, E. Felton and B. Dawson-Andoh
}

\begin{abstract}
Biodegradation is the only degradation pathway that is able to completely remove a polymer or its degradation products from the environment. Biodegradation takes place in two different conditions depending upon the presence of oxygen; aerobic biodegradation (in the presence of oxygen) and anaerobic biodegradation (in the absence of oxygen). This study examined the biodegradability of four different starch-lignin biocomposites reinforced with pulp fibers by invitro digestibility of the ruminant process. Biodegradation of the specimens were examined from a 6-hr period to a 48-hr period. Biodegradation of the four composite mixtures correlated with starch type. Amylose containing composite mixtures (\#1 and \#2) were associated with similar digestion rates; Composite \#1 biodegraded at 12.13\%/hr. and Composite \#2 biodegraded at $12.95 \% / \mathrm{hr}$. The best digestion rate was exhibited by amylopectin containing mixture Composite \#3 biodegraded at $14.00 \% / \mathrm{hr}$. and Composite \#4 biodegraded at $7.26 \% / \mathrm{hr}$., making it the composite that takes the longest to biodegrade. Therefore, meaning that the interaction between the composites fillers had an effect on the digestion rates of the starch-lignin composites.
\end{abstract}

\section{INTRODUCTION}

Definition of biodegradation depends on the field of application of the polymers (biomedical area or natural environment). Many different definitions have officially been adopted, depending on the background of the defining standard organizations and their particular interests. Biodegradation can be defined as an event that takes place through the action of enzymes and/or chemical decomposition associated with living organisms and their secretion products (Albertsson et al 1994). It is also necessary to consider abiotic reactions like photodegradation, oxidation and hydrolysis, which may alter the polymer before, during or instead of biodegradation because of environmental factors. So, strictly speaking, "biodegradation of a polymer' is defined as the deterioration of its physical and chemical properties and a decrease of its molecular mass down to the formation of carbon dioxide $\left(\mathrm{CO}_{2}\right)$, water $\left(\mathrm{H}_{2} \mathrm{O}\right)$, methane $\left(\mathrm{CH}_{4}\right)$ and other low molecular-weight products under the influence of microorganisms in both aerobic 
and anaerobic conditions aided by abiotic chemical reactions like photodegradation, oxidation and hydrolysis (Albertsson et al 1994 and Wang et al 2003).

Biodegradation is the only degradation path way that is able to completely remove a polymer or its degradation products from the environment. Biodegradation takes place in two stages. The first stage is the depolymerization of the macromolecules into shorter chains. This step normally occurs outside the organism due to the size of the polymer chain and the insoluble nature of many polymers. Extra-cellular enzymes (endo or exo-enzymes) and abiotic reactions are responsible for the polymeric chain cleavage. During this phase, the contact area between the polymer and the microorganism increases (Albertsson et al 1994, Hamid et al 1992, and Chandra et al 1998). The second step corresponds to the mineralization. Once sufficient small size oligomeric fragments are formed, they are transported into cells where they are bioassimilated by the microorganisms and then mineralized (Albertsson et al 1994, Grima et al 2000 and Swift et al 1995).

Biodegradation takes place in two different conditions depending upon the presence of oxygen; aerobic biodegradation (in the presence of oxygen) and anaerobic biodegradation (in the absence of oxygen). Complete biodegradation or mineralization occurs when no residue remains, i.e., when the original product is completely converted into gaseous products and salts (Kalia et al 2000). The Handbook of Biodegradable Polymeric Materials and Their Applications (Mallapragada et al 2005) provides a comprehensive review of the synthesis, characterization, processing, and applications of biodegradable polymers (polymeric biomaterials, biomedical engineering, food science and nutrition, green engineering, drug delivery, single-dose vaccines, protein stabilization, gene therapy, tissue engineering, orthopedics, and food packaging covering a broad spectrum of polymers such as polycaprolactones, polyesters, phosphazenes, phosphoesters, polyanhydrides, starch, chitosan and chitin) (Albertsson et al 1994 and Mallapragada et al 2005).

Starch is a polysaccharide consisting of D-glucopyranose units joined by $\alpha-1,4$ linkages. Starch consists of two different macromolecules, amylose and amylopectin (Averous et al 2009). Amylose is a sparsely branched carbohydrate bond with a molecular weight of $10^{5}-10^{6}$. Amylopectin is a highly multiple-branched polymer and in addition to the $\alpha-1,4$ linkages, also has $\alpha-1,6$ linkages with a high molecular weight of $10^{7}-10^{9} .^{2}$ The hydroxyl groups at $\mathrm{C}-2$ and $\mathrm{C}$ 3 positions on each glucose residue are free; as well as the primary hydroxyl group at C-6 when 
it is not linked ( $\mathrm{Lu}$ et al 2009 and Tomasik et al 2004). Evidently, starch is hydrophilic. The available hydroxyl groups on the starch chains potentially exhibit reactivity specific for alcohols. In other words, they can be oxidized and reduced; may participate in the formation of hydrogen bonds, ethers and esters ( $\mathrm{Lu}$ et al 2009 and Tomasik et al 2004).

Different proportions of amylose and amylopectin occur in starch and range from 10-20\% amylose and 80-90\% amylopectin depending on the source can be found (Lu et al 2009, Ramesh et al 1999 and Wallace et al 1981). Amylose is soluble in water and forms helical structure. Starch occurs naturally as discrete granules since the short branched amylopectin chains are able to form helical structures which crystallize (Lu et al 2009, Ramesh et al 1999 and Wallace et al 1981). A starch granule is hydrophilic with strong inter-molecular association via hydrogen bonding formed by the hydroxyl groups on the granule surface ( $\mathrm{Lu}$ et al 2009).

Lignin is a polymeric natural product arising from an enzyme-initiated dehydrogenative polymerization of the three primary precursors: 1 . trans-coniferyl, 2. trans-sinapyl and 3. trans-pcoumaryl alcohols (Sarkanen et al 1971). Lignins are always associated with hemicelluloses, not only in intimate physical admixture but also anchored to the latter by actual covalent bonds. Secondly, most lignins contain varying amounts of certain aromatic carboxylic acids in ester-like combination. These acids are most probably not generated from the three primary precursors in the dehydrogenative polymerization process (Sarkanen et al 1971).

This study examined the biodegradability of four different starch-lignin biocomposites by ruminal in vitro digestibility.

\section{EXPERIMENTAL}

\subsection{Materials}

Two types of starch biopolymers were used in this study, one contained $99 \%$ amylopectin and the other contained $25 \%$ amylose. The plasticizing agent, glycerol, was purchased from Fisher Scientific Inc. (Pittsburgh, PA). Kraft Lignin - Indulin AT@ was supplied by MeadWestvaco (Charleston, SC) and "Pure" Lignin was provided by Pure Lignin Environmental Technology (Kelowna, British Columbia - Canada). Pulp, bleached and unbleached, was used as reinforcing agents in the starch composite. Bleached pulp was supplied by Fibrek (Fairmont, WV) and unbleached pulp was provided by Weyerhaeuser (Columbus, MS). 


\subsection{Pre-Processing of Matrix}

Starch samples and reagent grade glycerol from Fisher Scientific were used together to prepare the thermostarch. Starch was kept in oven at $50^{\circ} \mathrm{C}$ to keep moisture content down. Starch and glycerol, $30 \% \mathrm{w} / \mathrm{w}$ of glycerol to starch, were premixed in polyethylene bags until a powder was obtained. The amount of fiber in the composite was calculated as a percentage of the total dry weight of starch plus glycerol. The use of $10 \% \mathrm{w} / \mathrm{w}$ pulp fibers (bleached and unbleached) were added accordingly.

\subsection{Processability of starch}

Starch and filler blends were processed as described previously (page 25). Briefly, starchglycerol-pulp fibers-lignin mixture $(25 \mathrm{~g})$ was loaded into the pre-heated chamber at $130^{\circ} \mathrm{C}$. The temperature throughout the process was maintained at this temperature. The rotors operated at $35 \mathrm{rpm}$ and the mixture was discharged after five minutes. A $5 \mathrm{~kg}$ dead weight was put on top of the mixer head throughout the experiments. All composites were run in triplicates to obtain average values for the gelation characteristics. A paste of starch, lignin and pulp fibers were obtained and used for compression-molding.

\subsection{Molding}

Composite mixtures were placed into molding for pressing into the desired shape, dogbones and bars, following ASTM-D4703-10A. The composite mixtures were placed in an oven @ 50 $\mathrm{C}$ for at least 24 hours and then were prepared for the press. The press used was a Carver Hydraulic Laboratory Press (Model 12-10HC) with safety shield. Used Reynolds Wrap@ Non Stick on the pressing molds and 770-NC solution to keep the samples from sticking to the molds; pressed the samples into the mold @ $130^{\circ} \mathrm{C}$ and 20,000 psi for five minutes. All dogbones (Type V, Thickness of 3.2 millimeters and length of 2.5 inches) were individually weighed and counted.

\subsection{Sample Preparation}

Dog-bone samples of the four composites were ground with a Mr. Coffee ${ }^{\circledR}$ coffee grinder to a consistent mesh size and weighed to 1g. Empty ANKOM®F57 bags were then weighed and sealed to be used as blanks for the experiment. Samples of the four composites were then placed 
in ANKOM ${ }^{\circledR} F 57$ bags, weighed and sealed. Starch samples were also placed in ANKOM®F57 bags, weighed and sealed. Each sample was done in quadruplets, but the blanks and starch samples were done in pairs for each of the four time periods (6-hrs, 12-hrs, 24-hrs and 48-hrs).

\subsection{Digestion of Samples in Ruminal In-Vito System}

Weighed ANKOM®F57 bags of blanks, starch and composites are then incubated in rumen buffered fluid for 6-hrs, 12 -hrs, $24-\mathrm{hrs}$ and 48 -hrs at $39^{\circ} \mathrm{C}$ in the DAISY ${ }^{\mathrm{II}}$ Incubator. After the incubation period, bags were rinsed with tap water and dried in a $55^{\circ} \mathrm{C}$ forced-air oven for 48 hrs. Any left-over remains were carefully removed from the ANKOM®F57 bags and weighed accordingly.

\section{RESULTS AND DISCUSSION}

Results of data analysis are presented in Table 9. Biodegradation of all composite samples were almost complete at the end of the 48-hrs incubation period. Although, starch composites were completely biodegraded after 48 hours, starch represent only about $80 \%$ biodegraded starch composites at the same period. It therefore be inferred that starch matrix interaction with the filler components had an effect on the digestion rates of composites. Biodegradation occurred faster in Kraft lignin composites and slower in "Pure" lignin samples: Composite \#1 biodegraded at $12.13 \% / \mathrm{hr}$., Composite \#2 biodegrades at $12.95 \% / \mathrm{hr}$., Composite \#3 biodegrades at 14.00\%/hr. and Composite \#4 biodegrades at 7.26\%/hr (Table 9).

\section{CONCLUSIONS}

In this study, biodegradation of four different starch-lignin composites reinforced with pulp fibers were tested. Biodegradation of the specimens were examined from a 6-hr period to a 48hr period. Biodegradation of the four composite mixtures correlated with starch type. Amylose containing composite mixtures (\#1 and \#2) had similar digestion rates; Composite \#1 biodegraded at $12.13 \% / \mathrm{hr}$. and Composite \#2 biodegrades at $12.95 \% / \mathrm{hr}$. The highest digestion rate was exhibited by amylopectin containing mixture. Composite \#3 biodegraded at 14.00\%/hr. while Composite \#4 biodegraded at 7.26\%/hr., making it the composite that took the longest to biodegrade. Therefore, the interaction between the composites fillers has an effect on the digestion rates of the starch-lignin composites. 


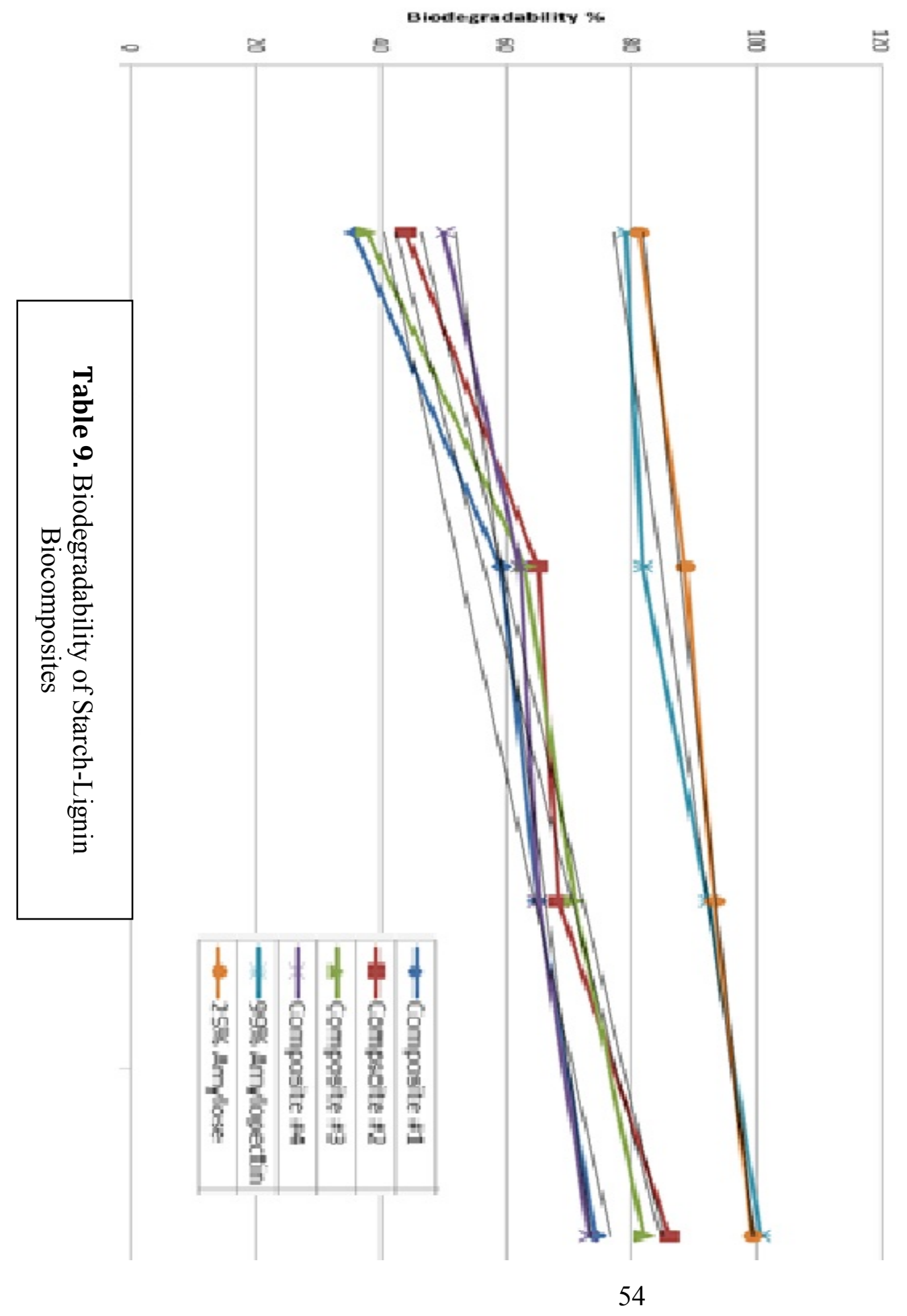




\section{References}

1. Albertsson AC, Karlsson S. Chemistry and Technology of Biodegradable Polymers. Blackie, Glasgow: 1994.

2. Averous, L. and Halley, P. Biocomposites based on plasticized starch. Wiley InterScience. 2009, 3, 329-343.

3. Calsamiglia, S. and Stern, M. A three-step in vitro procedure for estimating intestinal digestion of protein in ruminants. Journal of Animal Science 1995, Vol.73, 14591465.

4. Chandra R, Rustgi R (1998) Biodegradable polymers. Prog Polym Sci. 1998, Vol. 23, $1273-1335$.

5. Flieger, M., Kantorova, M., Prell, A., Řezanka, T. and Votruba, J. Biodegradable plastics from renewable sources. Folia microbiologica. 2003, Vol. 48, 27-44.

6. Grima S, Maurel VB, Feuilloley P, Silvestre F. Aerobic biodegradation of polymers in solid-state conditions: a review of environmental and physicochemical parameter settings in laboratory simulations. J Polym Environ. 2000, Vol. 8, 183-195

7. Hamid SH, Amin MB, Maadhah AG. Handbook of Polymer Degradation. Marcel Dekker, New York, Hong Kong: 1992

8. Kalia VC, Raizada N, Sonakya V. Bioplastics J Sci Ind. 2000, Vol. 59, 433-445.

9. Lu, D., Xiao, C., Xu, S. Starch-based completely biodegradable polymer materials. eXPRESS Polymer Letters. 2009, Vol. 3, No. 6, 366-375.

10. Luckachan, G. and Pillai, C. Biodegradable Polymers-A Review on Recent Trends and Emerging Perspectives. Journal of Polymers and the Environment. 2011, Vol. 19, 637-676.

11. Mallapragada S, Narasimhan B. The Handbook of Biodegradable Polymeric Materials and their Applications. American Scientific Publishers, USA: 2005

12. Sarkanen, K. and Ludwig, C. Lignins: Occurrence, Formation, Structure, and Reactions. New York: Wiley-Interscience edition 1971.

13. Selinger, L., Forsberg, C. and Cheng, K. The rumen: a unique source of enzymes for enhancing livestock production. Anaerobe. 1996, Vol.2, 263-284. 
14. Swift G. Opportunities for environmentally degradable polymers. J Macromol Sci Pure Appl Chem. 1995, Vol. 32, 641-651.

15. Ramesh, M., Mitchell, J. and Harding, S. Amylose content of rice starch. Starch. 1999, 51, 311-313.

16. Tomasik, P. and Schilling. Chemical Modification of Starch. Advances in Carbohydrate Chemistry and Biochemistry. 2004, Vol. 59, 175-403.

17. Wallace, R., King, J. and Sanders, G. Biology - The Science of life. California: Goodyear Publishing Company edition 1981.

18. Wang, XL, Yang, KK and Wang, YZ. J Macromol Sci Polym. 2003, Vol. 43, 385409

19. Wu, C. Physical properties and biodegradability of maleated-polycaprolactone/starch composite. Polymer degradation and stability. 2003, Vol. 80, 127-134. 


\section{GENERAL CONCLUSION}

The study of the processability of starch, lignin and pulp fibers using a Brabender® Torque Rheometer provided information that the type of starch exerted great influence on processability. Gelation characteristics of the four composite mixtures correlated with starch type. Amylose containing composite mixtures (\#1 and \#2) was associated with higher gelation characteristics. The lowest gelation torques and energies were exhibited by composites \#3 and \#4 (amylopectin starch). This can be attributed to the crystallinity melting temperature of the two starch composites. Amylopectin is the more crystalline structure of the two starches, so therefore would have the greater influence on such things as hardness, modulus, tensile and even stiffness, respectfully.

Higher mechanical properties were associated with starch bio-composites containing amylopectin. Composites \#1 and \#4 exhibited the highest water absorption and Composites \#2 and \#3 exhibited the lowest water absorption; the type of lignin used as filler made a greater contribution of the hydrophobicity of the starch composites. Moisture content of all starch composites was similar between all starch-lignin composites. Fourier Transform Infrared spectra analysis of composites showed the absence of any discernible chemical bonds. Bio-composites containing amylopectin exhibited the highest glass transition. Thermal degradation patterns for all starch composites were different. Mass loss below $100^{\circ} \mathrm{C}$ was associated with loss of water. Loss of glycerol commenced around $200^{\circ} \mathrm{C}$ and its thermal degradation was completed around $300^{\circ} \mathrm{C}$. Thermal degradation of pulp fiber occurred in two stages: $230^{\circ} \mathrm{C}$ and $230-390^{\circ} \mathrm{C}$ where the largest mass loss occurred. Scanning electron microscope showed that pulp fibers were not well dispersed and aligned within the composites.

Biodegradation of the samples were examined from a 6-hr period to a 48-hr period. Biodegradation of the four composite mixtures correlated with starch type. Amylose containing composite mixtures (\#1 and \#2) was associated with similar digestion rates; Composite \#1 biodegrades at $12.13 \% / \mathrm{hr}$. and Composite \#2 biodegrades at $12.95 \% / \mathrm{hr}$. The best digestion rate was exhibited by Amylopectin containing mixture Composite \#3 biodegrades at $14.00 \% / \mathrm{hr}$. and Composite \#4 biodegrades at $7.26 \% / \mathrm{hr}$., making it the composite that takes the longest to biodegrade. Therefore, meaning that the interaction between the composites fillers has an effect on the digestion rates of the starch-lignin composites. 


\section{RECOMMENDATIONS}

This work was a preliminary study to understand the processability, physical, mechanical, chemical and biodegradability of starch-lignin biocomposites reinforced with cellulose pulp. The results show that the starch exerted the greatest amount of influence on the composites. Still there are limitations in the current study that has to be address in future.

1. Better way of mixing and processing uniform biocomposites matrices.

2. Compare starch-lignin biocomposites mechanical and chemical properties to those that are used in the packing industry today.

3. Incubate the biocomposites for a longer time period to determine exactly how long it takes for the biocomposites to completely digest/biodegrade. 